\title{
Knowledge and attitudes of West Virginia Extension agents and high school agricultural educators with regard to meat goats and the meat goat industry
}

Angela L. Kirk

West Virginia University

Follow this and additional works at: https://researchrepository.wvu.edu/etd

\section{Recommended Citation}

Kirk, Angela L., "Knowledge and attitudes of West Virginia Extension agents and high school agricultural educators with regard to meat goats and the meat goat industry" (2006). Graduate Theses, Dissertations, and Problem Reports. 2359.

https://researchrepository.wvu.edu/etd/2359

This Thesis is protected by copyright and/or related rights. It has been brought to you by the The Research Repository @WVU with permission from the rights-holder(s). You are free to use this Thesis in any way that is permitted by the copyright and related rights legislation that applies to your use. For other uses you must obtain permission from the rights-holder(s) directly, unless additional rights are indicated by a Creative Commons license in the record and/ or on the work itself. This Thesis has been accepted for inclusion in WVU Graduate Theses, Dissertations, and Problem Reports collection by an authorized administrator of The Research Repository @ WVU. For more information, please contact researchrepository@mail.wvu.edu. 
Knowledge and Attitudes of West Virginia Extension Agents and High School Agricultural Educators with Regard to Meat Goats and the Meat Goat Industry

Angela L. Kirk

Thesis submitted to the Davis College of Agriculture, Forestry, and Consumer Sciences at West Virginia University in partial fulfillment of the requirements for the degree of

Master of Science
in
Agricultural and Environmental Education

Deborah A. Boone, Ph.D., Chair

Harry N. Boone, Jr. Ph.D. Stacy A. Gartin, Ph.D.

Division of Resource Management

Morgantown, West Virginia 2006

Key Words: Agricultural Education, Farm Diversification Meat Goats, Goat Industry 


\begin{abstract}
Knowledge and Attitudes of West Virginia Extension Agents and High School Agriculture Educators with Regard to Meat Goats and the Meat Goat Industry
\end{abstract}

Angela L. Kirk

The purpose of this study was to determine the knowledge and attitudes on meat goats and the meat goat industry in West Virginia by West Virginia Extension agents and high school agricultural teachers. A descriptive research design was selected for the study. A mailed questionnaire was sent to 51 Extension agents and 88 agriculture teachers who were the accessible population. Of the 139 agriculture educators 99 responded to the survey, for a response rate of $71.2 \%$. A majority (67.1\%) of Extension agents and high school agricultural teachers have noticed an increase in the meat goat industry in their areas and are aware of an interest in the meat goat industry within their communities. Very few $(22.2 \%)$ of the agricultural educators, however, have received formal training in meat goat production or the meat goat industry. Over three fourths $(79.8 \%)$ of the respondents have reported they would be willing to attend formal educational programs. 


\section{DEDICATION}

I would like to dedicate this thesis to my family. To my parents, Clinton and Sara Kirk, who has instilled in me incredible work ethic and determination to accomplish my goals. Without their knowledge, encouragement and support I would not have made it this far. And to my sister, Kelley Kirk, who is the best friend a person could have. She has been my biggest advocate and supporter. Thank you all for your love and support. 


\section{ACKNOWLEDGEMENTS}

It has been a long road, one that I could not have traveled with out the help and support of many individuals. I want to take the opportunity to thank my parents, Clinton and Sara Kirk, and my sister, Kelley Kirk, for their love, patience, and support. I want to thank my parents for purchasing my first goat for me as a 4-H project. I have come a long way since my first 4-H project and I owe it to my parents for allowing me to expand my 4-H project into a business.

Much thanks goes to Dr. Debby Boone. Thank you for being an outstanding advisor and support system. I could not have made it through this without your help and patience. You have been both supportive and encouraging. I sincerely appreciate everything you have done.

Dr. Harry Boone thank you for being an incredible teacher. Without your classes I am not sure I could have made it through this process. Thank you for making all of my “computer problems" look so easy. I am so glad and appreciative that you were there.

To Dr. Stacy Gartin thank you for believing in me and for all of the words of encouragement that you always had for me. It was a pleasure to have you on my committee.

I can not go without thanking all of the people at Potomac State College that have supported and backed me through this long process. To Dr. Kerry Odell thank you for your support and encouragement. Thank you for allowing me to do the things I enjoy most. To Sandy Smith, thank you for being a supporter, encourager, and friend. Thank you for putting up with me when I was stressed out about life. And to all of my students, 
thank you for your encouragement, excitement, and most of all support. You all have been great.

To Bob Mallow, you have truly been outstanding through all of this. You have had to deal with more than anyone, and yet you have hung in there. Thank you so much for being you. 


\section{TABLE OF CONTENTS}

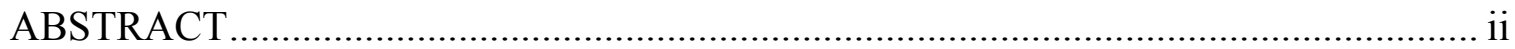

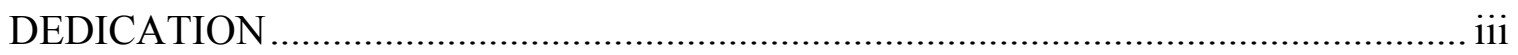

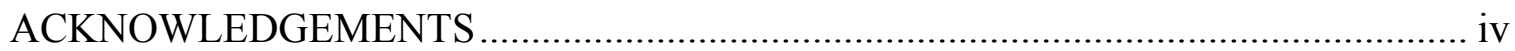

TABLE OF CONTENTS .................................................................................. vi

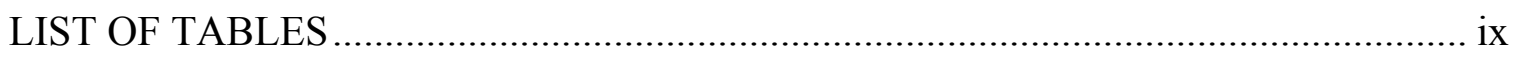

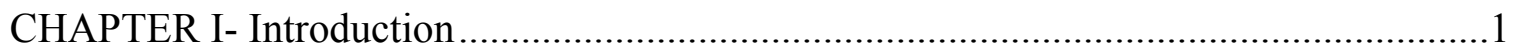

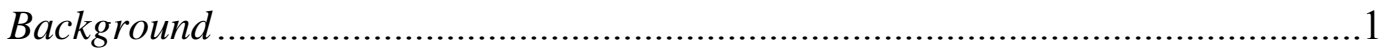

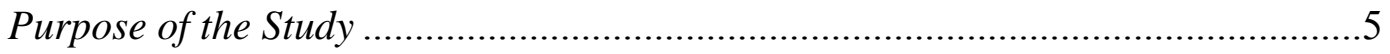

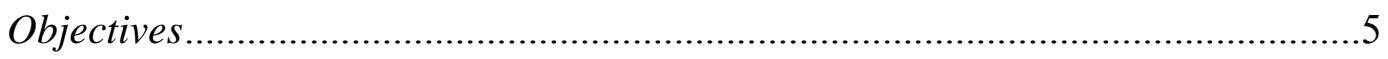

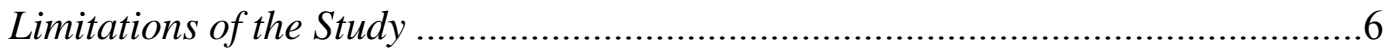

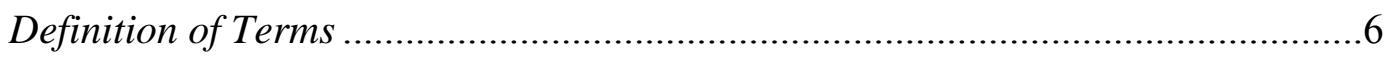

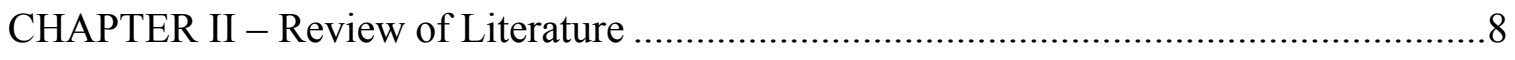

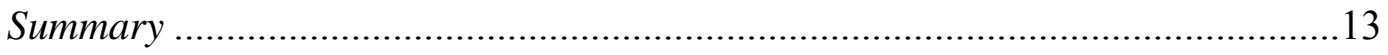

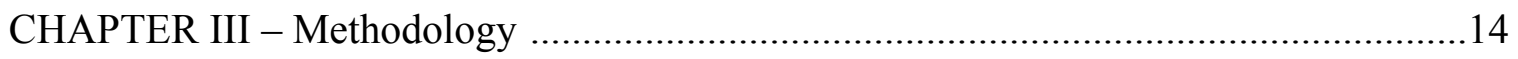

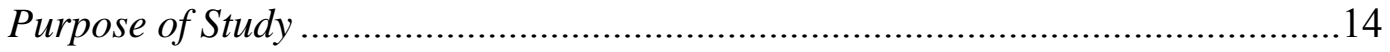

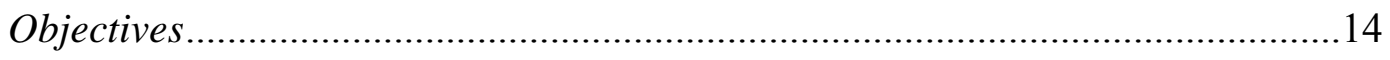

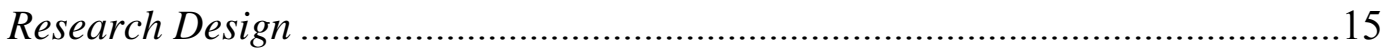

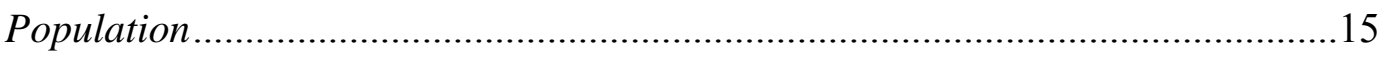

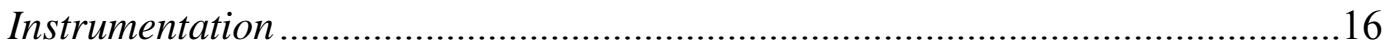

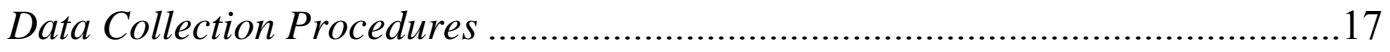

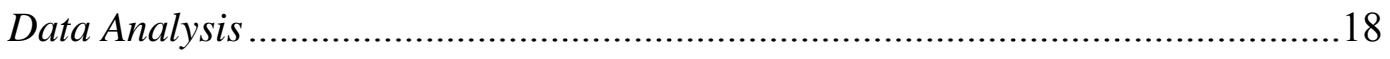

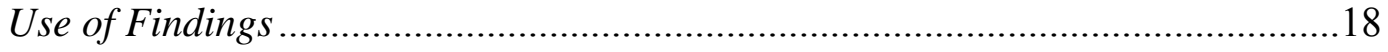




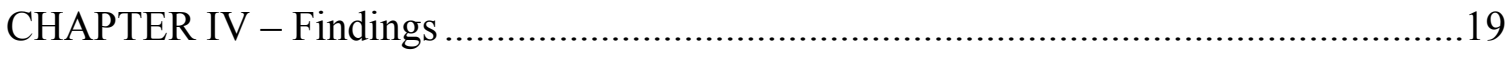

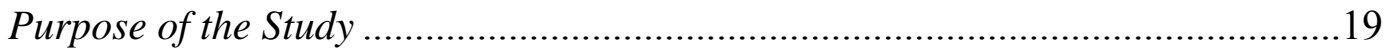

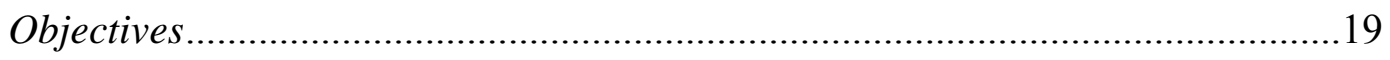

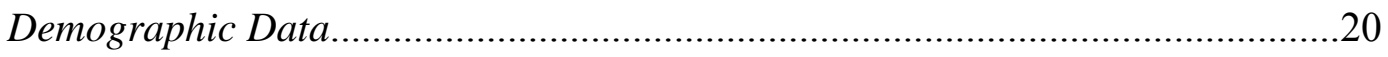

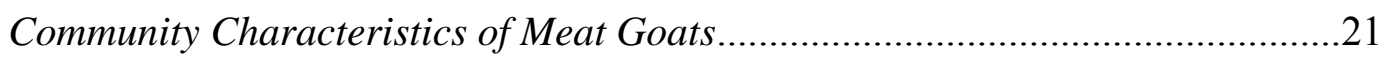

Agriculture Educators Knowledge of Goat Industry Practices ..............................24

Agriculture Educators Source of Knowledge …………........................................30

Agriculture Educators Confidence in Teaching Goat Industry

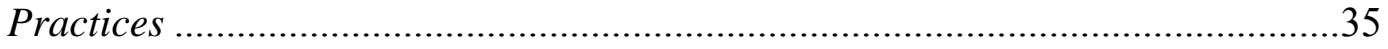

Agriculture Educators Teaching Methods of Meat Goat Practices.........................41

Agriculture Educators Teaching Over the Past Year ...........................................46

Agriculture Educators Attitudes on the Meat Goat Industry ...................................49

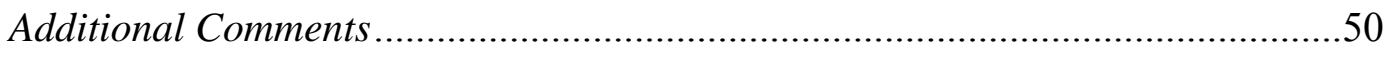

CHAPTER V- Summary, Conclusions and Recommendations ........................................53

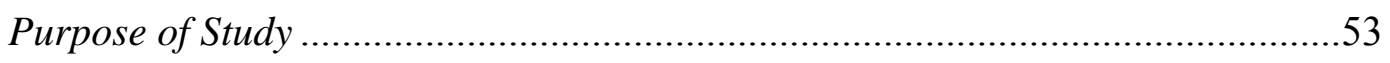

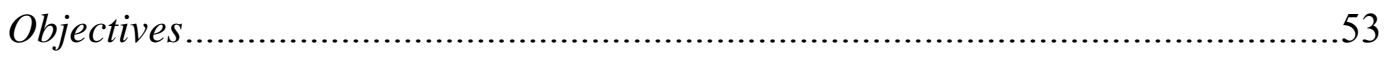

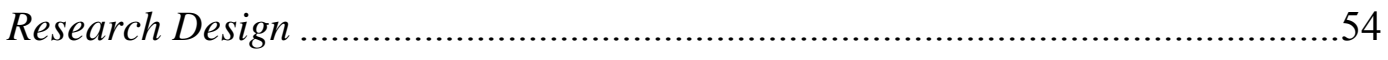

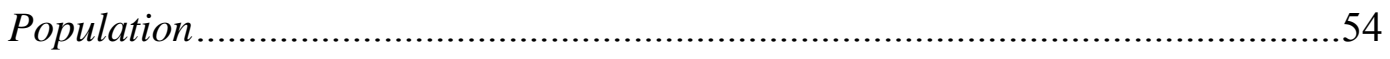

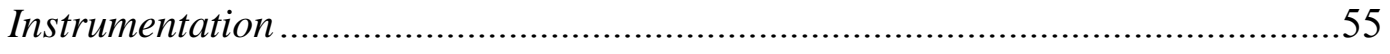

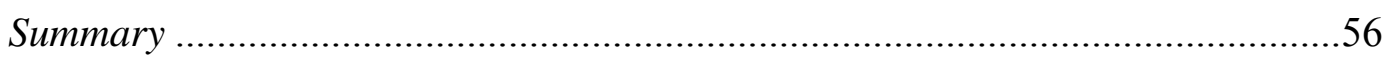

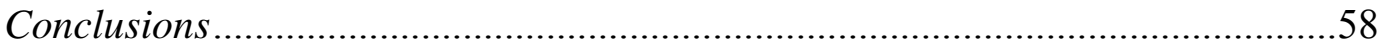

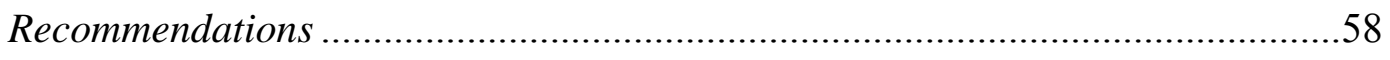

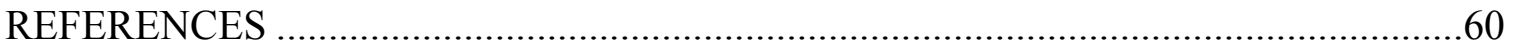

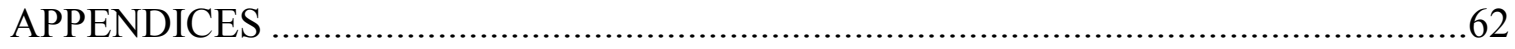


APPENDIX A: Survey Instrument

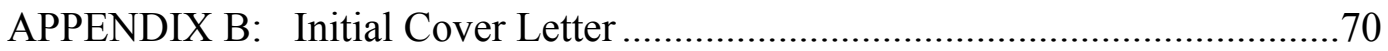

APPENDIX C: Follow- up Cover Letter ...................................................... 72

APPENDIX D: Open-ended Responses to Question 47 ....................................74

APPENDIX E: Open-ended Responses to Question 55 ...................................76

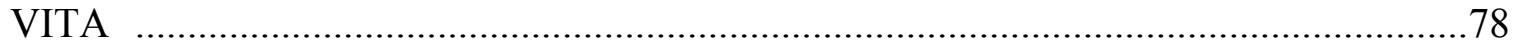




\section{LIST OF TABLES}

Table Title $\quad$ Page

1. Demographic Characteristics of Agriculture Educators in West

Virginia

2. Agriculture Educators Training and Knowledge of the Meat

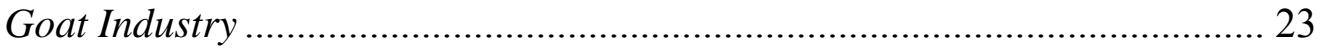

3. $\quad$ Agriculture Educators Views on the Demand for Goat Meat.......................... 23

4. $\quad$ Agriculture Educators Knowledge of Changes in the Meat

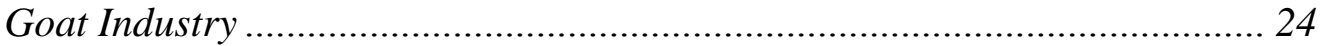

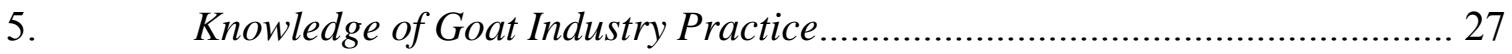

6. $\quad$ Sources of Knowledge of Selected Goat Industry Practices by

Agriculture Educators .................................................................... 31

7. Confidence Level of Performing and Teaching Skills................................. 37

8. $\quad$ Methods Used by Agriculture Educators to Teach Skills ..............................42

9. Number Times Topics Were Taught by Agriculture Educators

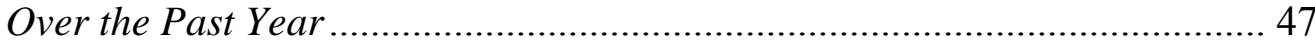

10. Agriculture Educators Attitudes on the Meat Goat Industry ........................ 51 


\section{CHAPTER I}

Introduction

\section{Background}

Land grant universities were established by the Morrill Act of 1862 "to educate citizens in agriculture, home economics, mechanical arts, and other practical professions" (About CSREES- Extension Background- Introduction, n.d., 9 6). The Smith- Lever Act of 1914 united agricultural colleges and the U.S. Department of Agriculture "to provide for cooperative extension work" (About CSREES- Extension Background- Introduction, n.d., 6). The combining of the Cooperative State Research Service and the Cooperative Extension Service formed the Cooperative State, Research, Education, and Extension Service (CSREES) in 1994 (CSREES Background, n.d. ๆ 1, ). The mission of CSREES "is to advance knowledge for agriculture, the environment, human health and well-being, and communities" (CSREES Background, n.d., p. 1, ๆ 3).

In the early twentieth century, "the 4-H idea of practical and "hands- on" learning came from the desire to make public school education more connected to country life" (4H History, n.d., $\llbracket 2$ ). At the same time researchers of land grant universities realized that adults were not acceptable to new discoveries in agriculture, however, the youth would take the new ideas and try them out and then report to adults their experiences and successes. This led to youth programs being developed as "a way to introduce new agricultural technology to adults” (4-H History, n.d., ๆ 3). A.B. Graham in 1902 started boys' and girls' clubs that were thought to have been the start of the 4-H program (4-H History, n.d., ๆ 3). Today, 4-H programs not only look at developing agricultural skills but "cultivates important life skills in youth that build character and assist them in 
making appropriate life and career choices" (About CSREES- Extension Background, n.d., p. 2, ๆ 6). Work in six areas: 4-H youth development, agriculture, leadership development, natural resources, family and consumer sciences, community and economic development; are focused on to meet the needs at the local level (About CSREESExtension Background, n.d., p. 2-3).

After the Smith-Lever Act established the Cooperative Extension Service, the Smith-Hughes Act was enacted in 1917. The Smith- Hughes Act was "the first national approval of vocational education in public school," "the act established vocational agriculture in areas of agriculture, trades and industry, and home economics" (Patterson, n.d., p.1, ๆ 1). "The agricultural education program provides a well rounded, practical approach to learning through three components: Classroom education in agricultural topics, hands on supervised agricultural career experience (SAE's), and FFA" (About FFA, n.d, 9 6). In 1928, the Future Farmers of America (FFA) was organized to support agricultural education (FFA History, n.d., $\mathbb{\uparrow} 1$ ). Today, the official name of the organization is The National FFA Organization. The mission of the FFA is, "dedicated to making positive difference in the lives of students by developing their potential for premier leadership, personal growth and career success through agricultural education" (About FFA, n.d., ๆ 1). Agriculture educators play a large role in educating both youth and adults through research and educational programs on marketing strategies such; as value added products, cattle and sheep pools, improved productivity through resource management, livestock production practices such as beef quality assurance programs, and income through alternative enterprises such as fish, goat, and buffalo production (About CSREES- Extension Background, n.d.). 
One alternative enterprise that appears to be gaining popularity is meat goat production. Agriculture educators, both high school teachers and Extension agents, need to increase their knowledge of meat goats in order to help the adults and youth in their communities.

Goats are known for being one of the earliest domesticated animals. However, it was not until the last decade that people started looking at goats as a valuable source of income. Goat meat is eaten more around the world than any other type of meat with goat meat representing about $65 \%$ of the red meat consumed in the world (Mauldin, 2004). The value of meat goats and production for human consumption did not catch on until the past few years. Over the past ten years the meat goat industry has been on a steady rise across the United States with most of the goat production originating in Texas. Interest in the meat goat industry has also risen in the eastern part of the United States. North Carolina is one of the many states that have seen a dramatic increase in the meat goat industry in 1995 with 27,874 head of meat goats sold at North Carolina auctions by 1998 over 35,000 goats were sold at the auctions (Luginbuhl, 2000). These figures do not include the number of animals that were sold directly off the farm.

The driving force in the meat goat industry can be credited to a number of factors. One of the major factors is the growing market for goat meat in the United States. The growing number of immigrants in the United States driving force for the goat meat market. The expanding ethnic groups entering the United States gives the future of the meat goat industry a bright future, "US census data indicated that more than 700,000 immigrants who prefer goat meat to other meats enter the USA each year" (Luginbuhl, 2000, p.1 ). The availability of goat meat has expanded into restaurants where it is being 
offered as gourmet food or as an ethnic food item. Goat meat is known for being lean, low in fat and calories, while being high in protein. As the number of immigrants entering the United States each year increases so will the demand for goat meat making for a solid and steady market.

Other factors have attracted individuals to enter the meat goat industry. Meat goats are a relatively easy enterprise to get started in as meat goats are highly adaptable to different climates and environments. They have high reproduction rates with an average of two kids being born per doe. They have high growth rates with Boer bucks reaching ninety pounds at three months of age and about two hundred pounds at one year old (Mauldin, 2004). Goats have a high carcass yield, with an average dressing percentage of 50\% (Luginbuhl, 1998). Part time farmers with limited space and facilities are able to raise enough animals to provide a supplemental income. Large scale farmers have also started incorporating meat goat enterprises on their farms. The diversification of these farms allows farmers to make use of land that cattle are unable to use. Meat goats have also been used to improve pasture conditions and feed quality, while providing additional income. Since, goats are primarily browsers and cattle are grazers they are not competing with each other for food. Eight goats can gather nutrition in an area where only one cow can roam. Thus, farmers can better utilize their land with diversification.

Growth of the meat goat industry can be seen on the farm and at auctions, as well as in the show ring. Goat shows are growing in both open and youth events. State and county livestock shows have started to include market goat shows in their youth livestock events. 
With the increasing demand for meat goats and the potential benefits associated with adding meat goats to farms it is important that agriculture educators are knowledgeable about meat goats and the meat goat industry. In order for agriculture educators to be able to inform and guide youth and adults in making decisions about production, management, and marketing programs need to be provided for the educators. Purpose of the Study

The purpose of this study was to determine the knowledge and attitudes on meat goats and the meat goat industry in West Virginia by West Virginia Extension agents and high school agriculture teachers. This study examined the educational needs of educators to better educate and work with meat goat producers in their communities.

\section{Objectives}

The objectives of this study are reflected in the following research questions.

1. What level of knowledge and understanding of meat goats is demonstrated by agriculture educators?

2. What level of knowledge does agriculture educators have about the meat goat industry in West Virginia?

3. What are the attitudes of agriculture educators toward the meat goat industry in West Virginia?

4. What educational activities on meat goats are offered by agriculture educators in West Virginia?

5. What educational activities are provided by West Virginia agriculture educators on the meat goat industry? 
6. What are West Virginia agriculture educators' perceptions of the size of the meat goat industry in West Virginia?

7. What are agriculture educators' perceptions of the role of the meat goat industry in West Virginia agriculture?

\section{Limitations}

This study was limited to West Virginia Extension Agents and West Virginia high school agriculture teachers.

Definition of Terms

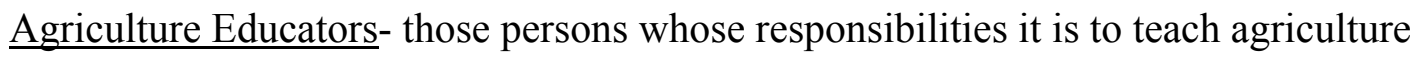
subjects to youth and adults such as Extension Agents and Agriculture teachers in High Schools.

Boer goats- type of meat goat of South African decent

Buck- a male goat.

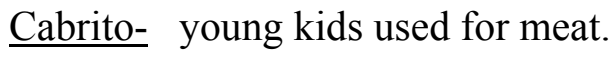

Crossbreeds- two breeds of goats crossed together to produce a meat goat with at least one of the parents being a meat goat.

Doe- female goat.

Ethnic Groups- groups of people from different ethnical backgrounds such as people from the Mediterranean, South Europe, Middle East, Africa, Southeastern Asia, Central America, and the West Indies.

FAMANCHA procedure- examining the lower eyelid of an animal to look for signs of anemia resulting from blood sucking parasites. 


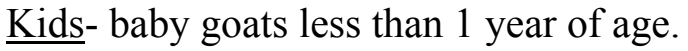

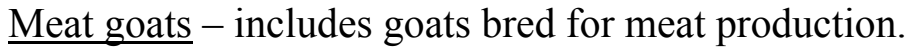

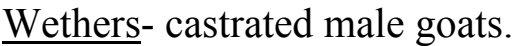




\section{CHAPTER II}

\section{Review of Literature}

"Meat goats are rarely the primary animal production enterprise in the United States, but they are becoming increasingly important contributors to the income of many producers" (Glimp, 1995, p. 1). The National Agricultural Statistical Service in 1998, reported that about 35,000 goats were slaughtered nationwide in 1977, when the USDA began keeping records of the number of goats slaughtered in federally inspected plants (as cited in Gipson, 2000). "By 1998, slaughter numbers had risen to nearly 450,000 a $1000 \%$ increase over the 20-year period" (Gipson, 2000, p. 1). The demand for goat meat is continually increasing with the demand expected to rise over the upcoming years. "Of the three red meat species only goat numbers have significantly increased over the last two decades. The other two, lamb and cattle, have decreased or remained steady" (Gipson, 2000, p. 1). Goat meat that was at one time exported out of the United States to other countries to meet demand is now being consumed in the United States (Coffey, 2002). The Foreign Agricultural Services data indicate that, "Even with this significant increase in domestic slaughter, the United States is a net importer of goat meat" (as cited in Gipson, 2000, p. 2). "Since 1989, importation of chilled frozen goat meat has continued to increase linearly while exportation of goat meat has decreased quadratically" (Gipson, 2002, p. 2).

One of the main contributors to the increase of goat meat importation and consumption in the United States is the increased ethnic diversity in the United States. Many of the immigrants to the United States are Hispanic, Muslim, Asian, and Caribbean people and they are from parts of the world where goat meat is the main red meat 
available (Mauldin, 2004; Coffey, 2002). "The U.S. Census Bureau projects that between 1995 and 2050, Hispanics will account for 57\% of the immigration into the United States, and that Hispanics will account for $25 \%$ of the United States population by 2050" (Coffey, 2002, p. 5). Pinkerton (1995) reported, the highest populations of Hispanics are found in Texas, California, New York, Southwestern United States, and the Northeast. "The vast majority of the Muslims in the United States reside in the urban belt stretching from Washington, D.C. to Boston, MA. Two cities in the United States account for a majority of the Caribbean immigrants, Miami and New York City" (as cited in Gipson, 2000).

The ethnic market is critical to the meat goat industry especially around the ethnic holidays. During the ethic holidays the demand for goat meat is at its peak (Schoenian, n.d). The largest demand seems to occur during Easter. Two weeks before Easter the number of goats slaughtered doubles (Gipson, 2000). "This market is driven by the Greek and Italian ethic populations residing in the urban Northeast" (Gipson, 2000, p. 4). There is a difference in preference, between ethnic groups, in the type and weight of meat goats purchased. Caribbean's prefer mature bucks, Muslims prefer goats with a carcass weight of 35lbs ( 70 lbs. live), and Hispanics prefer cabrito, young kids, with a carcass weight of 15-25lbs. (30- 50 lbs. live weight) (Gipson, 2000). The cabrito market of Mexicans and the Muslim clientele keep a market for kids year around (Gipson, 2000). Ethnic calendars are available listing the dates for the ethic holidays and the type and weight of meat goats desired (Schoenian, 2005).

Other markets for goat meat include reaching those that are health conscience. Goat meat is comparable to chicken in calories and protein, but is actually lower in total 
and saturated fat (Luginbuhl, 2000). The low amount of fat in goat meat is due to the fact that as the goat fattens the meat does not marble like many red meats do, instead it accumulates as waste on the outside of the meat and is removed before consumption (Coffey, 2002). Goat meat is also being seen as gourmet items in restaurant menus that feature ethnic entrées (Schoenian, n.d).

The total goat inventory, including angora, dairy, meat and other goats, for the United States in 2006 increased 4\% from 2005, with a total of 2.83 million goats. Of the 2.83 million goats in the U.S., 2,260,000 of those goats were considered meat or other goats. This number does not include angora or dairy goats. The inventory for meat and other goats in West Virginia is up 1.1\% from 2005, with West Virginia showing 17,500 goats in 2005 and 19,000 goats in 2006 (National Agricultural Statistical Service, 2006).

The increase in the goat industry can also be contributed to the characteristics of meat goats that have made them both profitable and beneficial. "The goat has proven to be perhaps the most adaptable of all the domestic livestock. Indeed, the goat survives worldwide in a wide range of environmental conditions" (Luginbuhl, 1998, p. 3). Goats have begun to play a major role as biological control agents in controlling weeds and brush. "Research conducted at the North Carolina Department of Agriculture Mountain Research Station in Waynesville has demonstrated that goats have significant economic value in biological control of weeds and brush in land reclamation projects" (Luginbuhl, 2000, p. 4). "The role of goats as biological control agents will become increasingly important in the future due to environmental concerns and elevated cost of other control methods such as mechanical cutting and herbicidal application" (Luginbuhl, 1998, p. 1). Brush infests much of the hill side pasture in the Appalachian region. Magadlela et al. 
(1995) (as cited in Luginbuhl, Green, Mueller, \& Poore, 1998, p. 2) reported that goats reduced the brush cover from $45 \%$ to $15 \%$ on a right-of-way in West Virginia in one year. The same result was achieved by sheep only; it took three years compared to the one year with goats. In five years of grazing the goats had reduced the brush cover to $2 \%$ "Goats alone were the least expensive method for clearing brush at $\$ 33 \mathrm{ha}^{-1}$ whereas herbicide application followed by goats or sheep at $\$ 593 \mathrm{ha}^{-1}$, was the most expensive method" (Luginbuhl et al., 1998, p. 2). Goats have the ability to benefit farms with their abilities to control problem weeds and brush such as: kudzu, leafy spurge, multiflora rose, knap weed, thistle, chick weed, honeysuckle, and other problem plants (Coffey, 2002; Luginbuhl et al., 1998). Grazing studies have shown that given a choice, goats will obtain $50 \%$ of their daily rations from browsing rather than grazing (Luginbuhl, 1998, p. 3). Since goats are primarily browsers they do not compete with cattle for food. Beef farmers have found that they can add goats to their beef herds and have additional profits plus cleaner pastures (Coffey, 2002). Luginbuhl (as cited in Coffey, 2002) stated that "you can add one or two goats per head of cattle without reducing beef production."

The passing of the Smith- Lever Act in 1914 and the Smith Hughes Act of 1917 brought agricultural education to the public through extension and public schools. Supervised agricultural experience programs and $4-\mathrm{H}$ projects have been used to guide youth in developing leadership, management, as well as other skills that will help them throughout their careers. Meat goats as youth projects, in 4-H and as supervised agricultural experience programs, have been increasing. This increase can be seen from the increase in numbers at county and state wide fairs. The West Virginia State Fair initiated a junior exhibitor meat goat show in 2001 and 14 meat goats were shown in the 
4-H and FFA show. In 2005, 82 meat goats were shown at the State Fair of West Virginia in the 4-H and FFA youth show. The State Fair of West Virginia began hosting an open meat goat show in 2004, sponsored by the American Boer Goat Association. In 2004156 Boer goats were exhibited. In the 2005 State Fair of West Virginia 220 Boer goats were exhibited. Exhibitors at the State Fair came from across the state as well as having exhibitors from Ohio, North Carolina, Pennsylvania, and Virginia participating (R.S. Rogers, personal communication, March 2, 2006). McKinney (n.d.) supports the idea of meat goats as a project for youth because of the low cost associated with meat goats. They are easily maintained and safe for youth to handle. The Research, Education, and Economics Information System Reports for 4-H Curriculum for 1996 showed 28,446 youth enrolled in a 4-H goat project. Reports for 2003 showed 101,955 youth enrolled in a 4-H goat project (REEIS, 1996, 2003).

"University research and extension programs in production, processing, and marketing of goat meat are scarce and should be initiated and sustained to assist in rapid, orderly industry development" (Pinkerton, Harwell, Drinkwater, and Escobar, 1994, p. 4). Systems need to be developed to help producers limit the variation in animal availability, body weights, and carcass characteristics; and to develop an effective marketing system (Pinkerton et al., 1994). Agriculture educators are a means of developing such systems. First, the educators have to be knowledgeable. Supervised agricultural research findings show that the quality of students' SAE's depends on the teachers' knowledge and understanding of the SAE. "Harris reported that agriculture teachers who recognize the educational value of SAE tended to have students with higher quality SAE programs" (as cited in Hoover and Arrington, n.d). Programs need to be 
provided to the educators in order for them to educate youth and people in their areas. Research has showed that "teachers perceived themselves as having acquired the majority of the competency areas through college courses, on-the-job activities, and through home study" (Findlay, 1992, p. 29).

\section{Summary}

The demand for goat meat is continually increasing as well as the meat goat industry. There is a large market available to meat goat producers and profit to be made. Along with meat goats being profitable they are beneficial and can easily be incorporated into a diversified farm. The meat goat industry has many things to offer both new and old farmers, as well as youth. As this industry continues to grow it is important that our agriculture educators grow with it. Agriculture educators need to learn more about meat goats and the meat goat industry to help the up and coming meat goat producers develop a successful market. 


\section{CHAPTER III}

\section{Methodology}

\section{Purpose of the Study}

The purpose of this study was to determine the knowledge and attitudes on meat goats and the meat goat industry in West Virginia by West Virginia Extension agents and high school agriculture teachers. This study examined the educational needs of educators to better educate and work with meat goat producers in their communities.

\section{Objectives}

The objectives of this study are reflected in the following research questions.

1. What level of knowledge and understanding of meat goats is demonstrated by agriculture educators?

2. What level of knowledge does agriculture educators have about the meat goat industry in West Virginia?

3. What are the attitudes of agriculture educators toward the meat goat industry in West Virginia?

4. What educational activities are offered by agriculture educators in West Virginia on meat goats?

5. What educational activities are provided by West Virginia agriculture educators on the meat goat industry?

6. What are West Virginia agriculture educators' perceptions of the size of the meat goat industry in West Virginia?

7. What are agriculture educators' perceptions of the role of the meat goat industry in West Virginia agriculture? 


\section{Research Design}

A descriptive research design was selected to collect data from high school agriculture teachers and Extension agents, who by their positions would have the information necessary to answer the research questions for this study that employed a mailed questionnaire to collect the data. Descriptive research was used because "the data collected are the subjects' experiences and perspectives" (Ary, Jacobs, \& Razavieh, 2002, p. 425) related to meat goats and the meat goat industry in West Virginia. Descriptive statistics "enable researchers to organize, summarize, and describe observations" (Ary et. al, 2002, p. 118). Disadvantages of descriptive statistics include the small population and the fact that the information gathered can only describe the current situation and the situations may change at any time.

The mailed questionnaire was designed to collect information from West Virginia agriculture educators about their attitudes and knowledge of meat goats and the meat goat industry in West Virginia. "Mailed questionnaires make it possible to include a larger number of subjects as well as subjects in more diverse locations than is possible with interviews" (Ary, et. al, 2002, p. 384).

\section{Population}

The target population for this study was high school agriculture teachers and County Extension agents employed in West Virginia during the first three months of 2006. Extension agents with agriculture responsibilities were selected to participate in the study. If there was not an agent with agriculture responsibilities in a county then the survey was sent to the county chair person so that each county received a survey. The list of extension agents in West Virginia was identified through the WVU Extension Service 
2005 Directory. The list of high school agriculture educators was obtained from the West Virginia Secondary Agriculture Teachers and Schools Directory 2005- 2006. A total of 51 Extension agents were included in the accessible population. A total of 88 agriculture teachers were included in the accessible population. The lists were analyzed and compared to eliminate duplicate names from the final mailing list. To prevent frame error official directories were used to compile the list of agriculture teachers and Extension agents. Selecting every Extension agent and high school agriculture teacher with agriculture responsibilities controlled selection and sampling error.

\section{Instrumentation}

The survey instrument consisted of fifty-five questions designed to obtain the respondents' knowledge and attitudes of meat goats. The first part of the questionnaire collected information on the knowledge level, source of knowledge, confidence of knowledge, and teaching methods of agriculture educators on meat goats and the meat goat industry. The second part of the questionnaire collected information on the perspectives that the agriculture educators had in relation to meat goats and the meat goat industry.

The third and final part of the questionnaire asked educators to list areas on meat goats and the meat goat industry they were interested in obtaining more knowledge in. This section also included general demographic questions about their position in agriculture education, the types of livestock they personally own, and their knowledge of the demand, marketing, and industry related to meat goats in the area in which they serve. If the educators had attended any formal training in meat goat production they were asked to list the type of event and the number of contact hours in each event. 
The list of agriculture educators to receive the questionnaire was checked for accuracy and checked for duplication of names. Non- response error was accounted for by comparing early respondents to late respondents, since late respondents are similar to non-respondents (Ary, 2002, p. 408). An independent t- test was used to determine if the early and late respondents differed on their attitudes of the goat industry. No significant difference $(\alpha \leq .05)$ was found between the early and late respondents.

A panel of experts consisting of faculty members at West Virginia University examined the questionnaire to establish face and content validity. A copy of the questionnaire used in this study can be found in (see Appendix A). Reliability was determined by the split half procedure. Split half reliability analysis was the appropriate data analysis since the data collected was either nominal or ordinal in nature. Demographics were removed and the remainders of the data were used to determine reliability. The instrument was determined to have exemplary reliability of .9287 (Robinson, Shaver, and Wrightsman, 1991).

\section{Data Collection Procedures}

The questionnaire and cover letter (see Appendix B) were mailed to each individual in the target population. The cover letter assured confidentiality and explained the purpose of the study. It also explained they had the right to skip questions and that participation was completely voluntary. The letter was signed by the researcher and her faculty advisor. A stamped self-addressed envelope was included to help facilitate the return of the survey. The self-addressed return envelopes were coded for the purpose of identifying non-respondents. To insure confidentiality no names were used on the instruments and numbers were only used for identifying non-respondents. One week 
after the initial surveys were sent out reminders were sent to the target population via email. Two weeks after the initial surveys were mailed a follow-up letter (see Appendix C) and a second questionnaire were mailed to each non-respondent. Early and late respondents were recorded during the data collection process.

Data Analysis

Returned questionnaires were visually verified and entered into an Excel spreadsheet. The Statistical Package for the Social Sciences (SPSS) was used to analyze the data. Data analysis procedures included frequencies, percentages, and means to describe the population.

Use of Findings

The findings of this study will help determine the status of the knowledge base that West Virginia agriculture educators have on meat goats and the meat goat industry in West Virginia. The findings will help determine the areas in which educators need more knowledge and the types of programs they would benefit from. The findings will also indicate how the educators feel towards learning and educating people about meat goats. 


\section{CHAPTER IV}

\section{Purpose of the Study}

\section{Findings}

The purpose of this study was to determine the knowledge and attitudes on meat goats and the meat goat industry in West Virginia by West Virginia Extension agents and high school agriculture teachers. This study examined the educational needs of educators to better educate and work with meat goat producers in their communities.

\section{Objectives}

The objectives of this study are reflected in the following research questions:

1. What level of knowledge and understanding of meat goats is demonstrated by agriculture educators?

2. What level of knowledge does agriculture educators have about the meat goat industry in West Virginia?

3. What are the attitudes of agriculture educators toward the meat goat industry in West Virginia?

4. What educational activities on meat goats are offered by agriculture educators in West Virginia on?

5. What educational activities are provided by West Virginia agriculture educators on the meat goat industry?

6. What are West Virginia agriculture educators' perceptions of the size of the meat goat industry in West Virginia?

7. What are agriculture educators' perceptions of the role of the meat goat industry in West Virginia agriculture? 
The target population was limited to high school agriculture teachers and county Extension agents in West Virginia. A total of 139 agriculture educators were in the accessible population. Of the 139 agriculture educators 99 responded to the survey, for a response rate of $71.2 \%$. The purpose of this research was to examine the level of knowledge that agriculture educators in West Virginia had on meat goats as a whole, not to single out which group of educators knew more on the subject areas covered. For this reason data were not analyzed on an extension versus agriculture teacher basis.

\section{Demographic Data}

The demographic data of the agriculture educators indicated 46 respondents $(47.9 \%)$ were extension agents and 50 respondents $(52.1 \%)$ were agriculture education teachers. Forty-two respondents $(43.8 \%)$ reported raising beef cattle. Sheep were raised by 18 respondents $(18.8 \%)$ and horses by 15 respondents $(15.6 \%)$. Thirteen respondents (13.5\%) reported raising swine. Nine respondents $(9.4 \%)$ reported personally raising meat goats and poultry. Eight respondents $(8.3 \%)$ reported raising dairy goats. Only two respondents $(2.1 \%)$ reported raising dairy cattle. Of the respondents, twelve respondents $(12.5 \%)$ reported not raising any livestock and 35 individuals $(36.5 \%)$ reported not owning livestock (see Table 1). 
Table 1

Demographic Characteristics of Agriculture Educators in West Virginia

\begin{tabular}{|c|c|c|c|c|}
\hline & \multicolumn{2}{|c|}{ Yes } & \multicolumn{2}{|c|}{ No } \\
\hline & $N$ & $\%$ & $N$ & $\%$ \\
\hline \multicolumn{5}{|l|}{ Current Position } \\
\hline Extension Agents & 46 & 47.9 & 50 & 52.1 \\
\hline Agriculture Education Teacher & 50 & 52.1 & 46 & 47.9 \\
\hline \multicolumn{5}{|l|}{ Type of Livestock Raised } \\
\hline Beef Cattle & 42 & 43.8 & 54 & 56.3 \\
\hline Sheep & 18 & 18.8 & 78 & 81.3 \\
\hline Horses & 15 & 15.6 & 81 & 84.4 \\
\hline Swine & 13 & 13.5 & 83 & 86.5 \\
\hline Meat Goats & 9 & 9.4 & 87 & 90.6 \\
\hline Poultry & 9 & 9.4 & 87 & 90.6 \\
\hline Dairy Goats & 8 & 8.3 & 88 & 91.7 \\
\hline Dairy Cattle & 2 & 2.1 & 94 & 97.9 \\
\hline None of the Above & 12 & 12.5 & 84 & 87.5 \\
\hline Do not own Livestock & 35 & 36.5 & 61 & 63.5 \\
\hline
\end{tabular}

Community Characteristics of Meat Goats

Only twenty-one respondents $(22.1 \%)$ reported having any formal training in meat goat production or the meat goat industry. Sixty-nine respondents $(73.4 \%)$ reported they were aware of an interest in meat goats in their community (see Table 2).

Respondents were asked to report on the available markets meat goat producers have in their area. Sixty-two respondents (64.6\%) said that there were local livestock 
markets available for meat goat producers to sell their animals in the local community. Fifty-six respondents (58.3\%) reported that market goats were sold directly off the farm in their areas. Market club goat consignments were reported by 23 respondents (24\%) to be available for meat goat producers in their area. Seven respondents (7.3\%) reported goat pools were available for meat goats in their areas. Six respondents (6.3\%) reported having registered goat consignment sales available to meat goat producers to market their goats. Eight respondents $(8.3 \%)$ reported having no markets available to meat goat producers in their area, while $20(20.8 \%)$ of the respondents admitted not knowing of available markets for meat goat producers to market meat goats in their area (see Table 2).

Forty-two respondents (43.8\%) believed there was a slight demand for goat meat within the meat goat industry. Thirty-one respondents (32.3\%) believed there was a moderate demand for goat meat within the industry and two respondents (2.1\%) believed there to be a high demand for goat meat. Four respondents (4.2\%) believed there was no demand for goat meat within the industry, while 17 respondents $(17.7 \%)$ did not know if a demand existed for goat meat within the industry (see Table 3 ). 
Table 2

Agriculture Educators Training and Knowledge of the Meat Goat Industry

\begin{tabular}{lrrrr}
\hline & \multicolumn{2}{c}{ Yes } & \multicolumn{2}{c}{ No } \\
\cline { 2 - 5 } & $N$ & $\%$ & $N$ & $\%$ \\
\hline Formal Training in Meat Goat Production and Industry & 21 & 22.1 & 74 & 77.9 \\
Knowledge of interest in meat goats in community & 69 & 73.4 & 25 & 26.6
\end{tabular}

Knowledge of available markets for meat goat producers

\begin{tabular}{lcccc} 
Local Livestock Markets & 62 & 64.6 & 34 & 35.4 \\
Directly off the Farm & 56 & 58.3 & 40 & 41.7 \\
Market Club Goat Consignments & 23 & 24.0 & 73 & 76.0 \\
Goat Pools & 7 & 7.3 & 89 & 92.7 \\
Registered Goat Consignment Sales & 6 & 6.3 & 90 & 93.8 \\
No Available Markets & 8 & 8.3 & 88 & 91.7 \\
Do Not Know of Available Markets & 20 & 20.8 & 76 & 79.2 \\
\hline
\end{tabular}

Table 3

Agriculture Educators Views on the Demand for Goat Meat

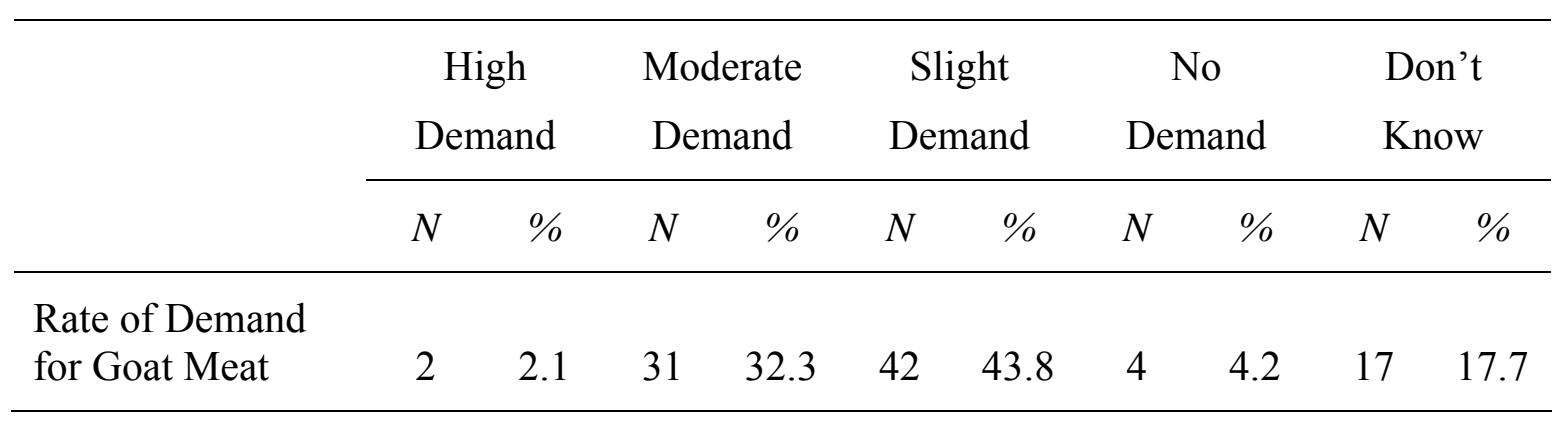


Fifty- three respondents $(67.1 \%)$ estimated that over the past five years an increase in the meat goat industry has occurred. Twenty-five respondents $(31.6 \%)$ reported that the meat goat industry stayed the same over the past five years. One respondent $(1.3 \%)$ estimated a decrease has occurred in the meat goat industry over the past five years (see Table 4).

Table 4

Agriculture Educators Knowledge of Changes in the Meat Goat Industry

\begin{tabular}{lcccccc}
\hline & \multicolumn{2}{c}{ Increased } & \multicolumn{2}{c}{ Decreased } & \multicolumn{2}{c}{ Stayed the Same } \\
\cline { 2 - 7 } & $N$ & $\%$ & $N$ & $\%$ & $N$ & $\%$ \\
\hline $\begin{array}{l}\text { Change in Meat Goat Industry } \\
\text { Over Past 5 Years }\end{array}$ & 53 & 67.1 & 1 & 1.3 & 25 & 31.6 \\
\hline
\end{tabular}

Agriculture Educators Knowledge of Goat Industry Practices

Respondents were asked to rate their knowledge on skills related to meat goats and the meat goat industry. The areas that respondents most frequently reported having no knowledge in included the FAMANCHA procedure $(\mathrm{n}=70,72.2 \%)$. FAMANCHA is a procedure used to determine the parasite load of an animal by examining the lower eyelid. Other areas that respondents most frequently reported having no knowledge in included nutrition of goat meat $(n=63,66.3 \%)$, embryo transfer $(n=60,62.5 \%)$, and artificial insemination $(\mathrm{n}=57,60.0 \%)$. The topics respondents were least likely to report no knowledge included tagging $(n=23,24.2 \%)$, nutritional requirements $(n=26$, $27.1 \%)$, breeds $(n=27,28.4 \%)$, and diseases $(n=29,29.9 \%)$ (see Table 5).

The topics respondents reported having "read about" included diseases, poisonous plants, breeds, and nutritional requirements for goats. Forty respondents (41.2\%) reported having read about goat diseases. Poisonous plants were "read about" by 38 
(38.4\%) respondents. Goat breeds was "read about" by 35 (36.8\%) of the respondents. Thirty-five respondents (36.5\%) have read about nutritional requirements for goats. Skills that were reported to be "read about" by the fewest respondents were the FAMANCHA procedure, hoof trimming, showing market goats, and showing registered goats. The FAMANCHA procedure was "read about" by seven (7.2\%) of the respondents. Ten (10.4\%) respondents had "read about" hoof trimming. Twelve (12.6\%) respondents had "read about" showing market goats and 14 individuals (14.6\%) had "read about" showing registered goats (see Table 5).

The topics respondents most frequently reported they "had seen performed" included the showing of market goats and registered goats, market show clipping, and registered show clipping performed the most. Of the respondents 37 responded that they "had seen" showing of market goats, while 34 (35.4\%) reported seeing registered goats show. Clipping goats for market shows "had been seen performed" by 33 (34.7\%), and $31(32.3 \%)$ respondents "has seen" clipping for registered shows performed. Skills that respondents reported in the "had seen performed" category the fewest times included embryo transfer, FAMANCHA procedure, artificial insemination, and types of breeds. Only $2(2.1 \%)$ respondents have seen embryo transfer performed. Six (6.2\%) respondents have seen artificial insemination performed. Of the respondents nine (9.5\%) have seen different carcass yields and breeds (see Table 5).

Skills the most respondents reported having performed themselves include tagging, tattooing, castrating, and hoof trimming. Tagging was reported by 27 respondents $(28.4 \%)$ in the performed themselves category. Twenty-four respondents (25.3\%) reported performing tattooing. Castration was performed by $24(25.0 \%)$ 
respondents. Twenty-three respondents $(24.0 \%)$ reported to performing hoof trimming. Skills that were reported the fewest times in the "having performed" category included embryo transfer, artificial insemination, ultrasound, and market show clipping. No $(0.0 \%)$ respondent had performed embryo transfer. Three respondents $(3.2 \%)$ had performed artificial insemination. Ultrasound and market show clipping were performed by four $(4.2 \%)$ respondents (see Table 5 ).

Skills that respondents most frequently reported possession of mastery in included tagging, castrating, breeds, and hoof trimming. Fifteen respondents (15.8\%) reported having mastery in tagging. Eleven $(11.5 \%)$ reported having mastery in castration. Nine respondents $(9.5 \%)$ possessed mastery in breeds, and nine $(9.1 \%)$ possessed mastery in kidding assistance. Topics that the fewest respondents reported possessing the mastery in included goat meat nutrition, embryo transfer, ultrasound, heart rate, diseases, FAMANCHA procedure, and clipping for registered shows. None of the respondents $(0.0 \%)$ felt they possessed mastery in embryo transfer. In goat meat nutrition, embryo transfer, ultrasound, heart rate, diseases, FAMANCHA procedure, and clipping for registered shows one respondent $(1.0 \%)$ that felt they possessed mastery of each of the skills (see Table 5). 
Table 5

Knowledge of Goat Industry Practices

\begin{tabular}{|c|c|c|c|c|c|c|c|c|c|c|}
\hline & \multicolumn{2}{|c|}{ No Knowledge } & \multicolumn{2}{|c|}{ Read About } & \multicolumn{2}{|c|}{ Seen Performed } & \multicolumn{2}{|c|}{ Performed Myself } & \multicolumn{2}{|c|}{ Possess Mastery } \\
\hline & $N$ & $\%$ & $N$ & $\%$ & $N$ & $\%$ & $N$ & $\%$ & $N$ & $\%$ \\
\hline Artificial Insemination & 57 & 60.0 & 27 & 28.4 & 6 & 6.3 & 3 & 3.2 & 2 & 2.1 \\
\hline Available Markets & 34 & 35.8 & 25 & 26.3 & 14 & 14.7 & 17 & 17.9 & 5 & 5.3 \\
\hline Breeds & 27 & 28.4 & 35 & 36.8 & 9 & 9.5 & 15 & 15.8 & 9 & 9.5 \\
\hline Carcass Yields & 49 & 51.6 & 27 & 28.4 & 9 & 9.5 & 7 & 7.4 & 3 & 3.2 \\
\hline Castrating & 29 & 30.2 & 16 & 16.7 & 16 & 16.7 & 24 & 25.0 & 11 & 11.5 \\
\hline Disbudding-Dehorning & 32 & 33.7 & 20 & 21.1 & 16 & 16.8 & 20 & 21.1 & 7 & 7.4 \\
\hline Diseases & 29 & 29.9 & 40 & 41.2 & 14 & 14.4 & 13 & 13.4 & 1 & 1.0 \\
\hline Embryo Transfer & 60 & 62.5 & 34 & 35.4 & 2 & 2.1 & 0 & .0 & 0 & .0 \\
\hline Ethnic Calendars & 50 & 52.1 & 27 & 28.1 & 6 & 6.3 & 10 & 10.4 & 3 & 3.1 \\
\hline FAMANCHA Procedure & 70 & 72.2 & 7 & 7.2 & 6 & 6.2 & 13 & 13.4 & 1 & 1.0 \\
\hline Fecal Analysis & 54 & 55.7 & 22 & 22.7 & 10 & 10.3 & 9 & 9.3 & 2 & 2.1 \\
\hline Genetics & 40 & 42.6 & 33 & 35.1 & 11 & 11.7 & 6 & 6.4 & 4 & 4.3 \\
\hline
\end{tabular}


Table 5 (continued)

Knowledge of Goat Industry Practices

\begin{tabular}{|c|c|c|c|c|c|c|c|c|c|c|}
\hline & \multicolumn{2}{|c|}{ No Knowledge } & \multicolumn{2}{|c|}{ Read About } & \multicolumn{2}{|c|}{ Seen Performed } & \multicolumn{2}{|c|}{ Performed Myself } & \multicolumn{2}{|c|}{ Possess Mastery } \\
\hline & $N$ & $\%$ & $N$ & $\%$ & $N$ & $\%$ & $N$ & $\%$ & $N$ & $\%$ \\
\hline Gestation & 32 & 33.3 & 31 & 32.3 & 12 & 12.5 & 14 & 14.6 & 7 & 7.3 \\
\hline Heart Rate & 49 & 51.0 & 30 & 31.3 & 10 & 10.4 & 6 & 6.3 & 1 & 1.0 \\
\hline Hoof Trimming & 33 & 34.4 & 10 & 10.4 & 22 & 22.9 & 23 & 24.0 & 8 & 8.3 \\
\hline Kidding Assistance & 43 & 43.4 & 19 & 19.2 & 10 & 10.1 & 15 & 15.2 & 9 & 9.1 \\
\hline Market show Clipping & 43 & 45.3 & 14 & 14.7 & 33 & 34.7 & 4 & 4.2 & 1 & 1.1 \\
\hline Nutrition of Goat Meat & 63 & 66.3 & 21 & 22.1 & 6 & 6.3 & 5 & 5.3 & 0 & 0.0 \\
\hline Nutritional Requirements & 26 & 27.1 & 35 & 36.5 & 16 & 16.7 & 14 & 14.6 & 5 & 5.2 \\
\hline Out of Season Breeding & 51 & 53.7 & 20 & 21.1 & 14 & 14.7 & 7 & 7.4 & 3 & 3.2 \\
\hline Parasite Control & 30 & 30.9 & 29 & 29.9 & 14 & 14.4 & 19 & 19.6 & 5 & 5.2 \\
\hline Poisonous Plant & 35 & 35.4 & 38 & 38.4 & 9 & 9.1 & 14 & 14.1 & 1 & 1.0 \\
\hline Predator Control & 30 & 31.6 & 25 & 26.3 & 12 & 12.6 & 22 & 23.2 & 6 & 6.3 \\
\hline Registered Show Clipping & 44 & 45.8 & 15 & 15.6 & 31 & 32.3 & 5 & 5.2 & 1 & 1.0 \\
\hline
\end{tabular}


Table 5 (continued)

Knowledge of Goat Industry Practices

\begin{tabular}{|c|c|c|c|c|c|c|c|c|c|c|}
\hline & \multicolumn{2}{|c|}{ No Knowledge } & \multicolumn{2}{|c|}{ Read About } & \multicolumn{2}{|c|}{ Seen Performed } & \multicolumn{2}{|c|}{ Performed Myself } & \multicolumn{2}{|c|}{ Possess Mastery } \\
\hline & $N$ & $\%$ & $N$ & $\%$ & $N$ & $\%$ & $N$ & $\%$ & $N$ & $\%$ \\
\hline Respiration & 49 & 51.6 & 28 & 29.5 & 10 & 10.5 & 7 & 7.4 & 1 & 1.1 \\
\hline Scrapies ID & 36 & 37.1 & 21 & 21.6 & 16 & 16.5 & 17 & 17.5 & 7 & 7.2 \\
\hline Selection & 40 & 42.1 & 22 & 23.2 & 18 & 18.9 & 11 & 11.6 & 4 & 4.2 \\
\hline Showing Market Goats & 33 & 34.7 & 12 & 12.6 & 37 & 38.9 & 9 & 9.5 & 4 & 4.2 \\
\hline Showing Registered Goats & 38 & 39.6 & 14 & 14.6 & 34 & 35.4 & 6 & 6.3 & 4 & 4.2 \\
\hline Tagging & 23 & 24.2 & 15 & 15.8 & 15 & 15.8 & 27 & 28.4 & 15 & 15.8 \\
\hline Tattooing & 36 & 37.9 & 14 & 14.7 & 17 & 17.9 & 24 & 25.3 & 4 & 4.2 \\
\hline Temperature & 41 & 42.3 & 29 & 29.9 & 12 & 12.4 & 11 & 11.3 & 4 & 4.1 \\
\hline Ultrasound & 51 & 53.1 & 22 & 22.9 & 18 & 18.8 & 4 & 4.2 & 1 & 1.0 \\
\hline Vaccination Program & 35 & 36.1 & 28 & 28.9 & 13 & 13.4 & 16 & 16.5 & 5 & 5.2 \\
\hline Weight Gain & 40 & 42.1 & 24 & 25.3 & 12 & 12.6 & 16 & 16.8 & 3 & 3.2 \\
\hline
\end{tabular}




\section{Agriculture Educators Source of Knowledge}

The agriculture educators were asked to identify their source(s) of knowledge about the skills of meat goat production and the meat goat industry. The topics most frequently listed in the high school agriculture program category included gestation, selection, poisonous plants, breeds, diseases, nutritional requirements, parasite control, and tagging. Fourteen respondents (14.1\%) obtained knowledge about gestation in the high school agriculture program. Eleven respondents (11.1\%) reported learning about selection and 10 respondents (10.1\%) acquired knowledge about poisonous plants in a high school agriculture program. Knowledge on breeds, diseases, nutritional requirements, parasite control, and tagging was acquired by nine respondents $(9.1 \%)$ from their high school agriculture program (see Table 6).

The topics most frequently listed in the knowledge from home or farm category included tagging, hoof trimming, kidding, and castration. Nineteen respondents (19.1\%) reported gaining their knowledge on tagging from their home or farm. Eighteen respondents (18.2\%) reported acquiring knowledge on hoof trimming from their home or farm. Seventeen respondents (17.2\%) reported gaining their knowledge of assisting in kidding and on castration from their home or farm (see Table 6).

The topics most frequently listed in the formal training category included castration, parasite control, vaccination programs, and genetics. Twenty-five respondents (25.3\%) reported gaining knowledge of castration through formal training. Knowledge from formal education in parasite control and vaccination programs was reported by 23 respondents (23.2\%). Twenty-one respondents (21.2\%) reported acquiring knowledge in genetics from formal education (see Table 6). 
Table 6

Sources of Knowledge of Selected Goat Industry Practices by Agriculture Educators

\begin{tabular}{|c|c|c|c|c|c|c|c|c|c|c|c|c|}
\hline & \multicolumn{2}{|c|}{ High School } & \multicolumn{2}{|c|}{ Home or Farm } & \multicolumn{2}{|c|}{$\begin{array}{c}\text { Formal } \\
\text { Education }\end{array}$} & \multicolumn{2}{|c|}{$\begin{array}{c}\text { Work } \\
\text { Experience }\end{array}$} & \multicolumn{2}{|c|}{ On the Job } & \multicolumn{2}{|c|}{ Internet } \\
\hline & $N$ & $\%$ & $N$ & $\%$ & $N$ & $\%$ & $N$ & $\%$ & $N$ & $\%$ & $N$ & $\%$ \\
\hline Artificial Insemination & 7 & 7.1 & 8 & 8.1 & 14 & 14.1 & 10 & 10.1 & 11 & 11.1 & 10 & 10.1 \\
\hline Available Markets & 5 & 5.1 & 12 & 12.1 & 12 & 12.1 & 26 & 26.3 & 31 & 31.3 & 13 & 13.1 \\
\hline Breeds & 9 & 9.1 & 8 & 8.1 & 18 & 18.2 & 21 & 21.2 & 32 & 32.2 & 10 & 10.1 \\
\hline Carcass Yields & 7 & 7.1 & 4 & 4.0 & 14 & 14.1 & 23 & 23.2 & 20 & 20.2 & 8 & 8.1 \\
\hline Castrating & 8 & 8.1 & 17 & 17.2 & 25 & 25.3 & 26 & 26.3 & 28 & 28.3 & 5 & 5.1 \\
\hline Disbudding-Dehorning & 6 & 6.1 & 15 & 15.2 & 19 & 19.2 & 21 & 21.2 & 30 & 30.3 & 8 & 8.1 \\
\hline Diseases & 9 & 9.1 & 12 & 12.1 & 20 & 20.2 & 25 & 25.3 & 27 & 27.3 & 17 & 17.2 \\
\hline Embryo Transfer & 5 & 5.1 & 6 & 6.1 & 15 & 15.2 & 9 & 9.1 & 11 & 11.1 & 11 & 11.1 \\
\hline Ethnic Calendars & 3 & 3.0 & 8 & 8.1 & 9 & 9.1 & 15 & 15.2 & 23 & 23.2 & 15 & 15.2 \\
\hline $\begin{array}{l}\text { FAMANCHA } \\
\text { Procedure }\end{array}$ & 1 & 1.0 & 3 & 3.0 & 8 & 8.1 & 8 & 8.1 & 16 & 16.2 & 7 & 7.1 \\
\hline Fecal Analysis & 5 & 5.1 & 5 & 5.1 & 14 & 14.1 & 21 & 21.2 & 20 & 20.2 & 14 & 14.1 \\
\hline
\end{tabular}


Table 6 (continued)

Sources of Knowledge of Selected Goat Industry Practices by Agriculture Educators

\begin{tabular}{|c|c|c|c|c|c|c|c|c|c|c|c|c|}
\hline & \multicolumn{2}{|c|}{ High School } & \multicolumn{2}{|c|}{ Home or Farm } & \multicolumn{2}{|c|}{$\begin{array}{c}\text { Formal } \\
\text { Education }\end{array}$} & \multicolumn{2}{|c|}{$\begin{array}{c}\text { Work } \\
\text { Experience }\end{array}$} & \multicolumn{2}{|c|}{ On the Job } & \multicolumn{2}{|c|}{ Internet } \\
\hline & $N$ & $\%$ & $N$ & $\%$ & $N$ & $\%$ & $N$ & $\%$ & $N$ & $\%$ & $N$ & $\%$ \\
\hline Genetics & 7 & 7.1 & 10 & 10.1 & 21 & 21.2 & 20 & 20.2 & 24 & 24.2 & 11 & 11.1 \\
\hline Gestation & 14 & 14.1 & 16 & 16.2 & 20 & 20.2 & 22 & 22.2 & 26 & 26.3 & 13 & 13.1 \\
\hline Heart Rate & 7 & 7.1 & 8 & 8.1 & 13 & 13.1 & 13 & 13.1 & 20 & 20.2 & 10 & 10.1 \\
\hline Hoof Trimming & 6 & 6.1 & 18 & 18.2 & 16 & 16.2 & 19 & 19.2 & 32 & 32.3 & 7 & 7.1 \\
\hline Kidding Assistance & 6 & 6.1 & 17 & 17.2 & 15 & 15.2 & 18 & 18.2 & 19 & 19.2 & 7 & 7.1 \\
\hline Market show Clipping & 4 & 4.0 & 3 & 3.0 & 8 & 8.1 & 17 & 17.2 & 31 & 31.3 & 4 & 4.0 \\
\hline Nutrition of Goat Meat & 3 & 3.0 & 3 & 3.0 & 10 & 10.1 & 8 & 8.1 & 16 & 16.2 & 11 & 11.1 \\
\hline $\begin{array}{l}\text { Nutritional } \\
\text { Requirements }\end{array}$ & 9 & 9.1 & 14 & 14.1 & 21 & 21.2 & 26 & 26.3 & 28 & 28.3 & 17 & 17.2 \\
\hline $\begin{array}{l}\text { Out of Season } \\
\text { Breeding }\end{array}$ & 6 & 6.1 & 8 & 8.1 & 15 & 15.2 & 13 & 13.1 & 21 & 21.2 & 9 & 9.1 \\
\hline Parasite Control & 9 & 9.1 & 15 & 15.2 & 23 & 23.2 & 25 & 25.3 & 28 & 28.3 & 13 & 13.1 \\
\hline
\end{tabular}


Table 6 (continued)

Sources of Knowledge of Selected Goat Industry Practices by Agriculture Educators

\begin{tabular}{|c|c|c|c|c|c|c|c|c|c|c|c|c|}
\hline & \multicolumn{2}{|c|}{ High School } & \multicolumn{2}{|c|}{ Home or Farm } & \multicolumn{2}{|c|}{$\begin{array}{c}\text { Formal } \\
\text { Education }\end{array}$} & \multicolumn{2}{|c|}{$\begin{array}{c}\text { Work } \\
\text { Experience }\end{array}$} & \multicolumn{2}{|c|}{ On the Job } & \multicolumn{2}{|c|}{ Internet } \\
\hline & $N$ & $\%$ & $N$ & $\%$ & $N$ & $\%$ & $N$ & $\%$ & $N$ & $\%$ & $N$ & $\%$ \\
\hline Poisonous Plants & 10 & 10.1 & 10 & 10.1 & 18 & 18.2 & 20 & 20.2 & 25 & 25.3 & 19 & 19.2 \\
\hline Predator Control & 4 & 4.0 & 14 & 14.1 & 17 & 17.2 & 23 & 23.2 & 32 & 32.3 & 9 & 9.1 \\
\hline Registered Show & & & & & & & & & & & & \\
\hline Clipping & 2 & 2.0 & 5 & 5.1 & 7 & 7.1 & 18 & 18.2 & 29 & 29.3 & 4 & 4.0 \\
\hline Respiration & 6 & 6.1 & 8 & 8.1 & 12 & 12.1 & 15 & 15.2 & 19 & 19.2 & 10 & 10.1 \\
\hline Scrapies ID & 3 & 3.0 & 10 & 10.1 & 15 & 15.2 & 22 & 22.2 & 26 & 26.3 & 13 & 13.1 \\
\hline Selection & 11 & 11.1 & 8 & 8.1 & 20 & 20.2 & 20 & 20.2 & 25 & 25.3 & 7 & 7.1 \\
\hline Showing Market Goats & 6 & 6.1 & 5 & 5.1 & 8 & 8.1 & 21 & 21.2 & 35 & 35.4 & 6 & 6.1 \\
\hline $\begin{array}{l}\text { Showing Registered } \\
\text { Goats }\end{array}$ & 5 & 5.1 & 7 & 7.1 & 8 & 8.1 & 21 & 21.2 & 32 & 32.3 & 4 & 4.0 \\
\hline Tagging & 9 & 9.1 & 19 & 19.2 & 19 & 19.2 & 27 & 27.3 & 36 & 36.4 & 6 & 6.1 \\
\hline Tattooing & 5 & 5.1 & 13 & 13.1 & 14 & 14.1 & 22 & 22.2 & 30 & 30.3 & 6 & 6.1 \\
\hline
\end{tabular}


Table 6 (continued)

Sources of Knowledge of Selected Goat Industry Practices by Agriculture Educators

\begin{tabular}{|c|c|c|c|c|c|c|c|c|c|c|c|c|}
\hline & \multicolumn{2}{|c|}{ High School } & \multicolumn{2}{|c|}{ Home or Farm } & \multicolumn{2}{|c|}{$\begin{array}{c}\text { Formal } \\
\text { Education }\end{array}$} & \multicolumn{2}{|c|}{$\begin{array}{c}\text { Work } \\
\text { Experience }\end{array}$} & \multicolumn{2}{|c|}{ On the Job } & \multicolumn{2}{|c|}{ Internet } \\
\hline & $N$ & $\%$ & $N$ & $\%$ & $N$ & $\%$ & $N$ & $\%$ & $N$ & $\%$ & $N$ & $\%$ \\
\hline Temperature & 6 & 6.1 & 10 & 10.1 & 16 & 16.2 & 14 & 14.1 & 23 & 23.2 & 12 & 12.1 \\
\hline Ultrasound & 5 & 5.1 & 4 & 4.0 & 17 & 17.2 & 18 & 18.2 & 17 & 17.2 & 9 & 9.1 \\
\hline Vaccination Program & 6 & 6.1 & 16 & 16.2 & 23 & 23.2 & 26 & 26.3 & 23 & 23.2 & 14 & 14.1 \\
\hline Weight Gain & 7 & 7.1 & 9 & 9.1 & 14 & 14.1 & 19 & 19.2 & 29 & 29.3 & 7 & 7.1 \\
\hline
\end{tabular}


The topics most frequently listed in the work experience category included tagging, vaccination programs, nutritional requirements, castration, and available markets. Knowledge from work experience in tagging was reported by 27 respondents (27.3\%). Twenty-six (26.3\%) reported acquiring knowledge on vaccination programs, nutritional requirements, castration, and available markets through work experience (see Table 6).

The topics most frequently listed in the on the job category included tagging, showing market goats, showing registered goats, predator control, and hoof trimming. Thirty-six respondents (36.4\%) gained knowledge on tagging on the job. Knowledge on showing market goats was acquired by 35 respondents (35.4\%) on the job. Thirty-two (32.3\%) have acquired knowledge of showing registered goats, predator control, and hoof trimming on the job (see Table 6).

The topics most frequently listed in the Internet category included poisonous plants, diseases, nutritional requirements of goats, and ethnic calendars. The Internet has served as a source of knowledge on poisonous plants for 19 respondents (19.2\%). Seventeen respondents (17.2\%) used the Internet to acquire knowledge about diseases and nutritional requirements of goats. Fifteen respondents (15.2\%) have acquired knowledge about the ethnic calendar from the Internet (see Table 6).

\section{Agriculture Educators Confidence in Teaching Goat Industry Practices}

Extension agents and high school agriculture teachers were asked to rate their confidence level in teaching skills associated with meat goat production and the meat goat industry. The most respondents rated their confidence level as being "very low" in teaching or performing embryo transfer, followed by the FAMANCHA procedure, 
artificial insemination, and the nutrition of goat meat. Forty-five respondents (58.4\%) reported having very low confidence in teaching embryo transfer, 46 reported (54.1\%) having very low confidence in teaching the FAMANCHA procedure. Of the respondents 37 (46.8\%) reported having very low confidence in teaching artificial insemination, while 39 (46.4\%) reported having very low confidence in teaching goat meat nutrition. Fewest respondents reported having very low confidence in teaching or performing tagging, predator control, hoof trimming, and castration. Only 17 respondents (19.5\%) had very low confidence in tagging, 18 (21.2\%) have very low confidence in teaching predator control, 19 respondents (22.4\%) have very low confidence in hoof trimming, and only $20(23.0 \%)$ have very low confidence in castration (see Table 7).

The most respondents reported having low confidence in performing or teaching carcass yields, showing registered goats, genetic selection, and in ultrasound. Twenty-five (29.8\%) had low confidence in teaching about carcass yields, 25 (29.1\%) had low confidence in showing registered goats, 24 respondents (28.2\%) had low confidence in teaching or performing genetic selection, and 23 respondents (27.7\%) had low confidence in teaching or performing ultrasounds. The fewest respondents reported having low confidence in teaching or performing tagging, gestation, tattooing, and parasite control. Only eight respondents (9.2\%) had low confidence in being able to teach or perform tagging. Ten respondents $(11.5 \%)$ had low confidence in teaching about gestation, $10(11.6 \%)$ had low confidence in teaching or performing tattooing, and only twelve (13.2\%) had low confidence in teaching or performing parasite control (see Table 7). 
The most respondents reported having moderate confidence in teaching about or performing: weight gain, available markets, diseases, and nutritional requirements. Of the respondents $34(40.0 \%)$ had moderate confidence in teaching about weight gain, $29(33.7 \%)$ had moderate confidence in teaching about the available markets. Twenty-one respondents $(23.1 \%)$ had moderate confidence in teaching about diseases.

Table 7

Confidence Level of Performing and Teaching Skills

\begin{tabular}{|c|c|c|c|c|c|c|c|c|c|c|}
\hline & \multicolumn{2}{|c|}{ Very low } & \multicolumn{2}{|c|}{ Low } & \multicolumn{2}{|c|}{ Moderate } & \multicolumn{2}{|c|}{ High } & \multicolumn{2}{|c|}{ Very High } \\
\hline & $N$ & $\%$ & $N$ & $\%$ & $N$ & $\%$ & $N$ & $\%$ & $N$ & $\%$ \\
\hline $\begin{array}{l}\text { Artificial } \\
\text { Insemination }\end{array}$ & 37 & 46.8 & 21 & 26.6 & 13 & 16.5 & 5 & 6.3 & 3 & 3.8 \\
\hline $\begin{array}{l}\text { Available } \\
\text { Markets }\end{array}$ & 21 & 24.4 & 17 & 19.8 & 29 & 33.7 & 14 & 16.3 & 5 & 5.8 \\
\hline Breeds & 20 & 23.8 & 15 & 17.9 & 18 & 21.4 & 19 & 22.6 & 12 & 14.3 \\
\hline Carcass Yields & 27 & 32.1 & 25 & 29.8 & 23 & 27.4 & 6 & 7.1 & 3 & 3.6 \\
\hline Castrating & 20 & 23.0 & 12 & 13.8 & 20 & 23.0 & 17 & 19.5 & 18 & 20.7 \\
\hline $\begin{array}{l}\text { Disbudding- } \\
\text { Dehorning }\end{array}$ & 22 & 25.3 & 15 & 17.2 & 19 & 21.8 & 17 & 19.5 & 14 & 16.1 \\
\hline Diseases & 23 & 25.6 & 15 & 16.7 & 30 & 33.3 & 18 & 20.0 & 4 & 4.4 \\
\hline $\begin{array}{l}\text { Embryo } \\
\text { Transfer }\end{array}$ & 45 & 58.4 & 21 & 27.3 & 9 & 11.7 & 1 & 1.3 & 1 & 1.3 \\
\hline $\begin{array}{l}\text { Ethnic } \\
\text { Calendars }\end{array}$ & 37 & 43.5 & 15 & 17.6 & 18 & 21.2 & 11 & 12.9 & 4 & 4.7 \\
\hline $\begin{array}{l}\text { FAMANCHA } \\
\text { Procedure }\end{array}$ & 46 & 54.1 & 15 & 17.6 & 10 & 11.8 & 10 & 11.8 & 4 & 4.7 \\
\hline
\end{tabular}


Table 7 (continued)

Confidence Level of Performing and Teaching Skills

\begin{tabular}{|c|c|c|c|c|c|c|c|c|c|c|}
\hline & \multicolumn{2}{|c|}{ Very low } & \multicolumn{2}{|c|}{ Low } & \multicolumn{2}{|c|}{ Moderate } & \multicolumn{2}{|c|}{ High } & \multicolumn{2}{|c|}{ Very High } \\
\hline & $N$ & $\%$ & $N$ & $\%$ & $N$ & $\%$ & $N$ & $\%$ & $N$ & $\%$ \\
\hline Fecal Analysis & 36 & 40.9 & 22 & 25.0 & 17 & 19.3 & 10 & 11.4 & 3 & 3.4 \\
\hline Genetics & 22 & 25.9 & 24 & 28.2 & 21 & 24.7 & 12 & 14.1 & 6 & 7.1 \\
\hline Gestation & 25 & 28.7 & 10 & 11.5 & 21 & 24.1 & 24 & 27.6 & 7 & 8.0 \\
\hline Heart Rate & 30 & 34.9 & 15 & 17.4 & 20 & 23.3 & 16 & 18.6 & 5 & 5.8 \\
\hline $\begin{array}{l}\text { Hoof } \\
\text { Trimming }\end{array}$ & 19 & 22.4 & 14 & 16.5 & 23 & 27.1 & 15 & 17.6 & 14 & 16.5 \\
\hline $\begin{array}{l}\text { Market show } \\
\text { Clipping }\end{array}$ & 35 & 40.2 & 22 & 25.3 & 24 & 27.6 & 4 & 4.6 & 2 & 2.3 \\
\hline $\begin{array}{l}\text { Nutrition of } \\
\text { Goat Meat }\end{array}$ & 39 & 46.4 & 21 & 25.0 & 19 & 22.6 & 3 & 3.6 & 2 & 2.4 \\
\hline $\begin{array}{l}\text { Nutritional } \\
\text { Requirements }\end{array}$ & 25 & 27.5 & 15 & 16.5 & 29 & 31.9 & 15 & 16.5 & 7 & 7.7 \\
\hline $\begin{array}{l}\text { Out of Season } \\
\text { Breeding }\end{array}$ & 29 & 34.1 & 23 & 27.1 & 23 & 27.1 & 6 & 7.1 & 4 & 4.7 \\
\hline $\begin{array}{l}\text { Parasite } \\
\text { Control }\end{array}$ & 23 & 25.3 & 12 & 13.2 & 27 & 29.7 & 21 & 23.1 & 8 & 8.8 \\
\hline $\begin{array}{l}\text { Predator } \\
\text { Control }\end{array}$ & 18 & 21.2 & 18 & 21.2 & 15 & 17.6 & 21 & 24.7 & 13 & 15.3 \\
\hline $\begin{array}{l}\text { Registered } \\
\text { Show Clipping }\end{array}$ & 34 & 39.5 & 23 & 26.7 & 22 & 25.6 & 4 & 4.7 & 3 & 3.5 \\
\hline Respiration & 31 & 36.5 & 14 & 16.5 & 19 & 22.4 & 16 & 18.8 & 5 & 5.9 \\
\hline Scrapies ID & 27 & 30.7 & 13 & 14.8 & 27 & 30.7 & 13 & 14.8 & 8 & 9.1 \\
\hline Selection & 24 & 28.2 & 19 & 22.4 & 25 & 29.4 & 11 & 12.9 & 6 & 7.1 \\
\hline
\end{tabular}


Table 7 (continued)

Confidence Level of Performing and Teaching Skills

\begin{tabular}{|c|c|c|c|c|c|c|c|c|c|c|}
\hline & \multicolumn{2}{|c|}{ Very low } & \multicolumn{2}{|c|}{ Low } & \multicolumn{2}{|c|}{ Moderate } & \multicolumn{2}{|c|}{ High } & \multicolumn{2}{|c|}{ Very High } \\
\hline & $N$ & $\%$ & $N$ & $\%$ & $N$ & $\%$ & $N$ & $\%$ & $N$ & $\%$ \\
\hline $\begin{array}{l}\text { Showing } \\
\text { Market Goats }\end{array}$ & 23 & 27.4 & 19 & 22.6 & 26 & 31.0 & 13 & 15.5 & 3 & 3.6 \\
\hline $\begin{array}{l}\text { Showing } \\
\text { Registered } \\
\text { Goats }\end{array}$ & 28 & 32.6 & 25 & 29.1 & 23 & 26.7 & 7 & 8.1 & 3 & 3.5 \\
\hline Tagging & 17 & 19.5 & 8 & 9.2 & 17 & 19.5 & 20 & 23.0 & 25 & 28.7 \\
\hline Tattooing & 24 & 27.9 & 10 & 11.6 & 25 & 29.1 & 12 & 14.0 & 15 & 17.4 \\
\hline Temperature & 29 & 33.0 & 12 & 13.6 & 20 & 22.7 & 20 & 22.7 & 7 & 8.0 \\
\hline Ultrasound & 37 & 44.6 & 23 & 27.7 & 13 & 15.7 & 7 & 8.4 & 3 & 3.6 \\
\hline $\begin{array}{l}\text { Vaccination } \\
\text { Program }\end{array}$ & 25 & 28.4 & 13 & 14.8 & 23 & 26.1 & 19 & 21.6 & 8 & 9.1 \\
\hline Weight Gain & 25 & 29.4 & 14 & 16.5 & 34 & 40.0 & 8 & 9.4 & 4 & 4.7 \\
\hline
\end{tabular}

Twenty (22.7\%) had moderate confidence in teaching about nutritional requirements. The fewest respondents reported having moderate confidence in teaching about embryo transfer, the FAMANCHA procedure, ultrasound, and artificial insemination. Of the respondents only nine respondents (11.7\%) had moderate confidence in teaching or performing embryo transfer, $10(11.8 \%)$ had moderate confidence in teaching or performing the FAMANCHA procedure. Thirteen (15.7\%) of the respondents had moderate confidence in teaching or performing 
ultrasound, and 13 (16.5\%) felt moderately confident about artificial insemination (see Table 7).

The most respondents reported having the highest confidence in teaching about gestation, predator control, parasite control, and teaching and taking temperatures. Twenty-four respondents $(27.6 \%)$ had high confidence in teaching about gestation and $21(24.7 \%)$ had high confidence in teaching about predator control. Of the respondents 21 (23.1\%) had high confidence in teaching and performing parasite control, 20 respondents $(22.7 \%)$ had high confidence in teaching and taking temperatures. The fewest respondents reported having high confidence in performing or teaching embryo transfer, the nutrition of goat meat, clipping for market shows, and clipping for registered shows. Only one respondent $(1.3 \%)$ had high confidence in performing or teaching embryo transfer, three respondents (2.4\%) had high confidence in teaching about goat meat nutrition. Four respondents (4.6\%) had high confidence in teaching and performing clipping for market shows, four respondents (4.7\%) also had high confidence in performing and teaching about clipping for registered shows (see Table 7).

The most respondents reported having the very high confidence in being able to perform or teach tagging, castration, tattooing, and hoof trimming. Twenty-five respondents $(28.7 \%)$ had very high confidence in being able to perform and teach about tagging. Eighteen respondents (20.7\%) had very high confidence in performing and teaching about castration. Fifteen (17.4\%) of the respondents had very high confidence in performing and teaching about tattooing, while $14(16.5 \%)$ had very high confidence in performing and teaching hoof trimming. The fewest respondents 
reported having very high confidence in teaching or performing embryo transfer, clipping for market goat shows, nutrition of goat meat, and fecal analysis. Of the respondents, only one (1.3\%) felt very confident about performing and teaching embryo transfer, two $(2.3 \%)$ respondents felt very confident about performing or teaching about clipping for market shows. Two (2.4\%) respondents felt very confident in teaching about the nutrition of goat meat, three respondents felt very confident about performing and teaching about fecal analysis (see Table 7).

\section{Agriculture Educators Teaching Methods of Meat Goat Practices}

Respondents were asked to identify teaching methods they used to teach the skills associated with meat goat production and the meat goat industry. Skills that the most respondents reported not teaching include the nutrition of goat meat, carcass yields, fecal analysis, out of season breeding, and showing registered goats. Of the respondents $76(76.8 \%)$ reported they did not teach about the nutrition of goat meat and $75(75.8 \%)$ respondents reported not teaching about carcass yield and fecal analysis. Seventy-four (74.7\%) respondents reported not teaching about out of season breeding, while $73(73.7 \%)$ respondents reported not teaching about showing registered goats (see Table 8 ).

Lectures or discussions were most frequently used to teach parasite control, diseases, breeds, gestation, and available markets. Twenty-eight $(28.3 \%)$ respondents used lectures or discussion to teach parasite control. Lecture and discussion was used by $24(24.2 \%)$ respondents to teach about diseases and $22(22.2 \%)$ respondents used this method to teach about breeds. Twenty-one (21.2\%) respondents used lecture and discussion as a way to teach about gestation and available markets (see Table 8). 
Table 8

Methods Used by Agriculture Educators to Teach Skills

\begin{tabular}{|c|c|c|c|c|c|c|c|c|c|c|}
\hline & \multicolumn{2}{|c|}{ Did Not Teach } & \multicolumn{2}{|c|}{ Lecture/Discussion } & \multicolumn{2}{|c|}{ Demonstrations } & \multicolumn{2}{|c|}{ Live Animals } & \multicolumn{2}{|c|}{ Problem Solving } \\
\hline & $N$ & $\%$ & $N$ & $\%$ & $N$ & $\%$ & $N$ & $\%$ & $N$ & $\%$ \\
\hline $\begin{array}{l}\text { Artificial } \\
\text { Insemination }\end{array}$ & 71 & 71.7 & 11 & 11.1 & 4 & 4.0 & 1 & 1.0 & 1 & 1.0 \\
\hline Available Markets & 59 & 59.6 & 21 & 21.2 & 4 & 4.0 & 4 & 4.0 & 3 & 3.0 \\
\hline Breeds & 55 & 55.6 & 22 & 22.2 & 8 & 8.1 & 5 & 5.1 & 4 & 4.0 \\
\hline Carcass Yields & 75 & 75.8 & 9 & 9.1 & 4 & 4.0 & 1 & 1.0 & 1 & 1.0 \\
\hline Castrating & 63 & 63.6 & 12 & 12.1 & 7 & 7.1 & 6 & 6.1 & 5 & 5.1 \\
\hline $\begin{array}{l}\text { Disbudding- } \\
\text { Dehorning }\end{array}$ & 63 & 63.6 & 12 & 12.1 & 6 & 6.1 & 8 & 8.1 & 3 & 3.0 \\
\hline Diseases & 58 & 58.6 & 24 & 24.2 & 4 & 4.0 & 3 & 3.0 & 5 & 5.1 \\
\hline Embryo Transfer & 69 & 69.7 & 10 & 10.1 & 2 & 2.0 & 1 & 1.0 & 1 & 1.0 \\
\hline Ethnic Calendars & 71 & 71.7 & 9 & 9.1 & 4 & 4.0 & 1 & 1.0 & 1 & 1.0 \\
\hline $\begin{array}{l}\text { FAMANCHA } \\
\text { Procedure }\end{array}$ & 70 & 70.7 & 4 & 4.0 & 5 & 5.1 & 6 & 6.1 & 2 & 2.0 \\
\hline
\end{tabular}


Table 8 (continued)

Methods Used by Agriculture Educators to Teach Skills

\begin{tabular}{|c|c|c|c|c|c|c|c|c|c|c|}
\hline & \multicolumn{2}{|c|}{ Did Not Teach } & \multicolumn{2}{|c|}{ Lecture/Discussion } & \multicolumn{2}{|c|}{ Demonstrations } & \multicolumn{2}{|c|}{ Live Animals } & \multicolumn{2}{|c|}{ Problem Solving } \\
\hline & $N$ & $\%$ & $N$ & $\%$ & $N$ & $\%$ & $N$ & $\%$ & $N$ & $\%$ \\
\hline Fecal Analysis & 75 & 75.8 & 5 & 5.1 & 6 & 6.1 & 3 & 3.0 & 1 & 1.0 \\
\hline Genetics & 65 & 65.7 & 18 & 18.2 & 5 & 5.1 & 1 & 1.0 & 3 & 3.0 \\
\hline Gestation & 60 & 60.9 & 21 & 21.2 & 4 & 4.0 & 4 & 4.0 & 4 & 4.0 \\
\hline Heart Rate & 68 & 68.7 & 12 & 12.1 & 3 & 3.0 & 4 & 4.0 & 0 & 0.0 \\
\hline Hoof Trimming & 58 & 58.6 & 12 & 12.1 & 7 & 7.1 & 12 & 12.1 & 4 & 4.0 \\
\hline Kidding Assistance & 67 & 67.7 & 11 & 11.1 & 3 & 3.0 & 5 & 5.1 & 4 & 4.0 \\
\hline $\begin{array}{l}\text { Market show } \\
\text { Clipping }\end{array}$ & 67 & 67.7 & 10 & 10.1 & 3 & 3.0 & 8 & 8.1 & 1 & 1.0 \\
\hline $\begin{array}{l}\text { Nutrition of Goat } \\
\text { Meat }\end{array}$ & 76 & 76.8 & 7 & 7.1 & 3 & 3.0 & 1 & 1.0 & 0 & 0.0 \\
\hline $\begin{array}{l}\text { Nutritional } \\
\text { Requirements }\end{array}$ & 57 & 57.6 & 22 & 22.2 & 7 & 7.1 & 3 & 3.0 & 10 & 10.1 \\
\hline $\begin{array}{l}\text { Out of Season } \\
\text { Breeding }\end{array}$ & 74 & 74.7 & 9 & 9.1 & 4 & 4.0 & 1 & 1.0 & 2 & 2.0 \\
\hline
\end{tabular}


Table 8 (continued)

Methods Used by Agriculture Educators to Teach Skills

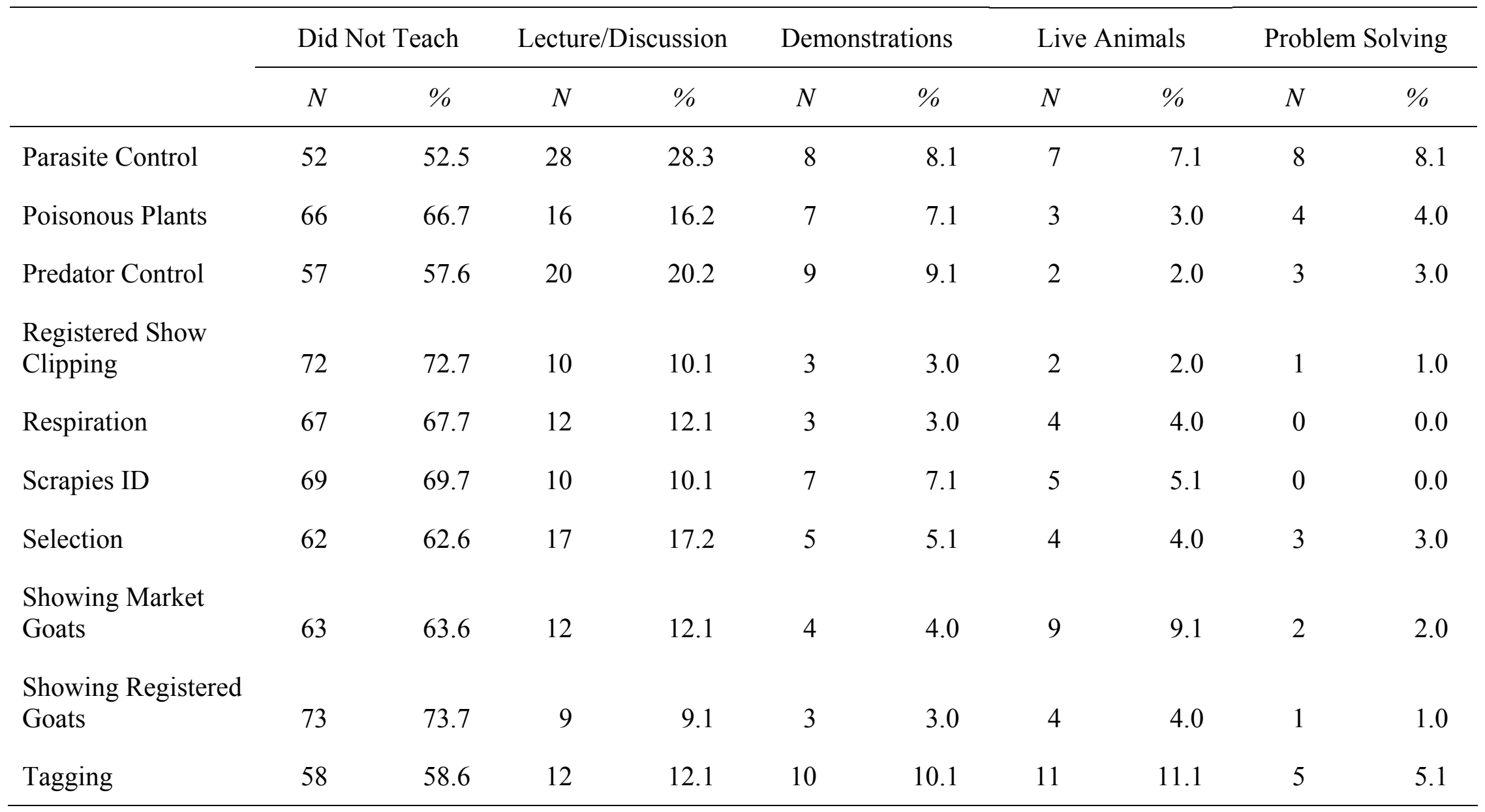


Table 8 (continued)

Methods Used by Agriculture Educators to Teach Skills

\begin{tabular}{|c|c|c|c|c|c|c|c|c|c|c|}
\hline & \multicolumn{2}{|c|}{ Did Not Teach } & \multicolumn{2}{|c|}{ Lecture/Discussion } & \multicolumn{2}{|c|}{ Demonstrations } & \multicolumn{2}{|c|}{ Live Animals } & \multicolumn{2}{|c|}{ Problem Solving } \\
\hline & $N$ & $\%$ & $N$ & $\%$ & $N$ & $\%$ & $N$ & $\%$ & $N$ & $\%$ \\
\hline Tattooing & 68 & 68.7 & 10 & 10.1 & 7 & 7.1 & 4 & 4.0 & 0 & 0.0 \\
\hline Temperature & 67 & 67.7 & 12 & 12.1 & 3 & 3.0 & 4 & 4.0 & 1 & 1.0 \\
\hline Ultrasound & 70 & 70.7 & 10 & 10.1 & 2 & 2.0 & 2 & 2.0 & 0 & 0.0 \\
\hline Vaccination & & & & & & & & & & \\
\hline Program & 60 & 60.6 & 19 & 19.2 & 9 & 9.1 & 4 & 4.0 & 5 & 5.1 \\
\hline Weight Gain & 64 & 64.6 & 18 & 18.2 & 5 & 5.1 & 3 & 3.0 & 2 & 2.0 \\
\hline
\end{tabular}


Respondents most frequently reported using demonstration to teach about tagging, vaccination programs, predator control, parasite control, and breeds. Ten respondents (10.1\%) used demonstration methods to teach about tagging and nine (9.1\%) used demonstrations to teach about vaccination programs and predator control. Of the respondents, eight (8.1\%) used demonstration methods to teach parasite control and breeds (see Table 8).

Respondents most frequently reported using live animal demonstration $\mathrm{s}$ to teach about hoof trimming, tagging, showing of market goats, and disbudding and dehorning. Live animal demonstrations were used by 12 respondents (12.1\%) to teach hoof trimming, 11respondents (11.1\%) used live animal demonstrations to teach tagging. Nine respondents (9.1\%) taught the showing of market goats by live animal demonstrations, while eight respondents (8.1\%) taught dehorning and disbudding using live animal demonstrations (see Table 8).

Respondents most frequently reported using student applied problems and problem solving to teach about parasite control, nutritional requirements of goats, diseases, vaccination programs, castration, and tagging. Ten respondents (10.1\%) taught nutritional requirements by using student applied problems and problem solving, eight (8.1\%) used this method to teach parasite control. The use of student applied problems and problem solving was used by 5 respondents $(5.1 \%)$ to teach about diseases, vaccination programs, castration, and tagging (see Table 8).

Agriculture Educators Teaching Over the Past Year

Respondents were asked how many times they taught each of the topics over the past year. Ultrasound was taught the most over the past year with a mean score of 3.60 
$(S D=7.54)$ followed by embryo transfer with a mean score of $3.00(S D=5.67)$. The mean score, for the times that fecal analysis was taught over the past year $1.82(S D=$ 1.32). Selection was taught by respondents over the past year with a mean of $1.75(S D=$ 1.11). The topics that was taught the least was kidding assistance with a mean of 1.15 $(S D=.555)$, followed by showing market goats and teaching about poisonous plants with a mean of $1.25(S D=.622)$, artificial insemination with a mean of $1.27(S D=.647)$, and hoof trimming with a mean of $1.29(S D=.644)$ (see Table 9).

Table 9

Number Times Topics Were Taught by Agriculture Educators Over the Past Year

\begin{tabular}{lcccc}
\hline & $N$ & $M$ & $S D$ & Max \\
\hline Ultrasound & 10 & 3.60 & 7.545 & 25 \\
Embryo Transfer & 11 & 3.00 & 5.675 & 20 \\
Fecal Analysis & 11 & 1.82 & 1.328 & 5 \\
Selection & 20 & 1.75 & 1.118 & 4 \\
Tagging & 19 & 1.74 & 1.661 & 8 \\
Genetics & 15 & 1.73 & 1.163 & 4 \\
Available Markets & 21 & 1.67 & 1.155 & 5 \\
Registered Show Clipping & 8 & 1.63 & .744 & 3 \\
Carcass Yields & 9 & 1.56 & 1.130 & 4 \\
Predator Control & 22 & 1.55 & 1.057 & 5 \\
FAMANCHA Procedure & 13 & 1.54 & .967 & 4 \\
Weight Gain & 17 & 1.53 & .874 & 4 \\
Scrapies ID & 16 & 1.50 & 1.155 & 5 \\
Out of Season Breeding & 10 & 1.50 & 1.080 & 4 \\
\hline
\end{tabular}


Table 9 (continued)

Number Times Topics Were Taught by Agriculture Educators Over the Past Year

\begin{tabular}{|c|c|c|c|c|}
\hline & $N$ & $M$ & $S D$ & Max \\
\hline Disbudding-Dehorning & 18 & 1.44 & .922 & 4 \\
\hline Ethnic Calendars & 9 & 1.44 & .726 & 3 \\
\hline Parasite Control & 30 & 1.43 & .626 & 3 \\
\hline Showing Registered Goats & 7 & 1.43 & .787 & 3 \\
\hline Market show Clipping & 12 & 1.42 & .669 & 3 \\
\hline Vaccination Program & 21 & 1.38 & .590 & 3 \\
\hline Gestation & 19 & 1.37 & .684 & 3 \\
\hline Tatooing & 11 & 1.36 & .809 & 3 \\
\hline Breeds & 25 & 1.36 & .638 & 3 \\
\hline Nutritional Requirements & 23 & 1.35 & .573 & 3 \\
\hline Diseases & 23 & 1.35 & .573 & 3 \\
\hline Heart Rate & 12 & 1.33 & .651 & 3 \\
\hline Nutrition of Goat Meat & 6 & 1.33 & .816 & 3 \\
\hline Castrating & 19 & 1.32 & .671 & 3 \\
\hline Temperature & 13 & 1.31 & .630 & 3 \\
\hline Respiration & 13 & 1.31 & .630 & 3 \\
\hline Hoof Trimming & 21 & 1.29 & .644 & 3 \\
\hline Artificial Insemination & 11 & 1.27 & .647 & 3 \\
\hline Poisonous Plants & 12 & 1.25 & .622 & 3 \\
\hline Showing Market Goats & 12 & 1.25 & .622 & 3 \\
\hline Kidding Assistance & 13 & 1.15 & .555 & 3 \\
\hline
\end{tabular}




\section{Agriculture Educators Attitudes on the Meat Goat Industry}

Of the respondents seven $(8.0 \%)$ reported they strongly disagreed with promoting market goat shows at the county level for youth. Five respondents (5.6\%) strongly disagreed with promoting the use of meat goats as a source of supplemental income. Five respondents (5.5\%) strongly disagree with favoring market goat shows at the county level for youth. Four respondents (4.3\%) strongly disagree with promoting the meat goat industry in West Virginia (see Table 10).

Twenty- three respondents (26.4\%) disagree with promoting market goat shows at the county level. Of the respondents $19(20.7 \%)$ disagree with promoting the meat goat industry in West Virginia. Sixteen respondents (18.2\%) disagree with the future of the meat goat industry in West Virginia. Sixteen (17.8\%) disagree with promoting the use of meat goats as a source of supplemental income (see Table 10).

Fifty-seven respondents (62.6\%) agree with using meat goats as a source of supplemental income. Of the respondents 54 (60.0\%) agree that goats benefit land improvements and land management, 51 respondents $(58.0 \%)$ agree that the future of the meat goat industry in West Virginia is strong. Fifty-two respondents (56.5\%) agree they would attend educational programs on raising meat goats (see Table 10).

Forty-one respondents (44.1\%) strongly agree that they are in favor of the meat goat industry in West Virginia. The future of the meat goat industry in West Virginia is strongly agreed with by 35 respondents (39.3\%). Thirty-five respondents (38.5\%) strongly agree with the potential of market goats as 4-H projects and SAE's. Thirty-four (37.8\%) of the respondents strongly agree with the benefits goats have on land improvements and management (see Table 10). 


\section{Additional Comments}

Respondents were asked what educational topics on meat goats they would be interested in attending programs on. Of the respondents that answered this question, the most were interested in attending programs on marketing and management. Some respondents reported that they would be interested in attending programs on everything (see Appendix D).

Respondents were asked to list the types of events in which they had received formal training in meat goat production or the meat goat industry. Of the respondents that had received formal training, six respondents had received training in the FAMANCHA procedure. Other areas that respondents had received training in include small ruminants, parasites, artificial insemination, and fecal egg counts. For a full list of training areas (see Appendix E). 
Table 10

Agriculture Educators Attitudes on the Meat Goat Industry

\begin{tabular}{|c|c|c|c|c|c|c|c|c|}
\hline & \multicolumn{2}{|c|}{ Strongly Disagree } & \multicolumn{2}{|c|}{ Disagree } & \multicolumn{2}{|c|}{ Agree } & \multicolumn{2}{|c|}{ Strongly Agree } \\
\hline & $N$ & $\%$ & $N$ & $\%$ & $N$ & $\%$ & $N$ & $\%$ \\
\hline I am in favor of the meat goat industry in WV & 0 & .0 & 1 & 1.1 & 51 & 54.8 & 41 & 44.1 \\
\hline I promote the meat goat industry in WV & 4 & 4.3 & 19 & 20.7 & 48 & 52.2 & 21 & 22.8 \\
\hline I see a future for the meat goat industry in WV & 0 & .0 & 6 & 6.7 & 48 & 53.9 & 35 & 39.3 \\
\hline $\begin{array}{l}\text { I am in favor of market goat shows at the county } \\
\text { level for youth }\end{array}$ & 5 & 5.5 & 7 & 7.7 & 46 & 50.5 & 33 & 36.3 \\
\hline $\begin{array}{l}\text { I promote market goat shows at the county level } \\
\text { for youth }\end{array}$ & 7 & 8.0 & 23 & 26.4 & 34 & 39.1 & 23 & 26.4 \\
\hline $\begin{array}{l}\text { I see the potential of market goats as } 4-\mathrm{H} \text { projects } \\
\text { and SAEs }\end{array}$ & 1 & 1.1 & 6 & 6.6 & 49 & 53.8 & 35 & 38.5 \\
\hline $\begin{array}{l}\text { I see the benefits goats have on land } \\
\text { improvements and management }\end{array}$ & 0 & .0 & 2 & 2.2 & 54 & 60.0 & 34 & 37.8 \\
\hline $\begin{array}{l}\text { I am in favor of using meat goats as a source of } \\
\text { supplemental income }\end{array}$ & 0 & .0 & 4 & 4.4 & 57 & 62.6 & 30 & 33.0 \\
\hline $\begin{array}{l}\text { I promote using meat goats as a source of } \\
\text { supplemental income }\end{array}$ & 5 & 5.6 & 16 & 17.8 & 48 & 53.3 & 21 & 23.3 \\
\hline
\end{tabular}


Table 10 (continued)

Agriculture Educators Attitudes on Meat Goat Industry

\begin{tabular}{|c|c|c|c|c|c|c|c|c|}
\hline & \multicolumn{2}{|c|}{ Strongly Disagree } & \multicolumn{2}{|c|}{ Disagree } & \multicolumn{2}{|c|}{ Agree } & \multicolumn{2}{|c|}{ Strongly Agree } \\
\hline & $N$ & $\%$ & $N$ & $\%$ & $N$ & $\%$ & $N$ & $\%$ \\
\hline $\begin{array}{l}\text { I believe the future of the meat goat industry in } \\
\text { WV is strong }\end{array}$ & 0 & .0 & 16 & 18.2 & 51 & 58.0 & 21 & 23.9 \\
\hline $\begin{array}{l}\text { I would attend an educational program on raising } \\
\text { meat goats }\end{array}$ & 1 & 1.1 & 12 & 13.0 & 52 & 56.5 & 27 & 29.3 \\
\hline
\end{tabular}




\section{CHAPTER V}

Summary, Conclusions, and Recommendations

\section{Purpose of the Study}

The purpose of this study was to determine the knowledge and attitudes on meat goats and the meat goat industry in West Virginia by West Virginia Extension agents and high school agriculture teachers. This study examined the educational needs of educators to better educate and work with meat goat producers in their communities.

\section{Objectives}

The objectives of this study are reflected in the following research questions.

1. What level of knowledge and understanding of meat goats is demonstrated by agriculture educators?

2. What level of knowledge does agriculture educators have about the meat goat industry in West Virginia?

3. What are the attitudes of agriculture educators toward the meat goat industry in West Virginia?

4. What educational activities are offered by agriculture educators in West Virginia on meat goats?

5. What educational activities are provided by West Virginia agriculture educators on the meat goat industry?

6. What are West Virginia agriculture educators' perceptions of the size of the meat goat industry in West Virginia?

7. What are agriculture educators' perceptions of the role of the meat goat industry in West Virginia agriculture? 


\section{Research Design}

A descriptive research design was selected to collect data from high school agriculture teachers and Extension agents, who by their positions would have the information necessary to answer the research questions for this study that employed a mailed questionnaire to collect the data. Descriptive research was used because "the data collected are the subjects' experiences and perspectives" (Ary, Jacobs, \& Razavieh, 2002, p. 425) related to meat goats and the meat goat industry in West Virginia. Descriptive statistics "enable researchers to organize, summarize, and describe observations" (Ary et. al, 2002, p. 118). Disadvantages of descriptive statistics include the small population and the fact that the information gathered can only describe the current situation and the situations may change at any time.

The mailed questionnaire was designed to collect information from West Virginia agriculture educators about their attitudes and knowledge of meat goats and the meat goat industry in West Virginia. "Mailed questionnaires make it possible to include a larger number of subjects as well as subjects in more diverse locations than is possible with interviews" (Ary, et. al, 2002, p. 384).

\section{Population}

The target population for this study was high school agriculture teachers and County Extension agents employed in West Virginia during the first three months of 2006. Extension agents with agriculture responsibilities were selected to participate in the study. If there was not an agent with agriculture responsibilities in a county then the survey was sent to the county chair person so that each county received a survey. The list of extension agents in West Virginia was identified through the WVU Extension Service 
2005 Directory. The list of high school agriculture educators was obtained from the West Virginia Secondary Agriculture Teachers and Schools Directory 2005- 2006. A total of 51 Extension agents were included in the accessible population. A total of 88 agriculture teachers were included in the accessible population. The lists were analyzed and compared to eliminate duplicate names from the final mailing list. To prevent frame error official directories were used to compile the list of agriculture teachers and Extension agents. Selecting every Extension agent and high school agriculture teacher with agriculture responsibilities controlled selection and sampling error.

\section{Instrumentation}

The survey instrument consisted of fifty-five questions designed to obtain the respondents' knowledge and attitudes of meat goats. The first part of the questionnaire collected information on the knowledge level, source of knowledge, confidence of knowledge, and teaching methods of agriculture educators on meat goats and the meat goat industry. The second part of the questionnaire collected information on the perspectives that the agriculture educators had in relation to meat goats and the meat goat industry.

The third and final part of the questionnaire asked educators to list areas on meat goats and the meat goat industry they were interested in obtaining more knowledge in. This section also included general demographic questions about their position in agriculture education, the types of livestock they personally own, and their knowledge of the demand, marketing, and industry related to meat goats in the area in which they serve. If the educators had attended any formal training in meat goat production they were asked to list the type of event and the number of contact hours in each event. 
The list of agriculture educators to receive the questionnaire was checked for accuracy and checked for duplication of names. Non- response error was accounted for by comparing early respondents to late respondents, since late respondents are similar to non-respondents (Ary, 2002, p. 408). An independent t- test was used to determine if the early and late respondents differed on their attitudes of the goat industry. No significant difference $(\alpha \leq .05)$ was found between the early and late respondents.

A panel of experts consisting of faculty members at West Virginia University examined the questionnaire to establish face and content validity. A copy of the questionnaire used in this study can be found in (see Appendix A). Reliability was determined by the split half procedure. Split half reliability analysis was the appropriate data analysis since the data collected was either nominal or ordinal in nature. Demographics were removed and the remainders of the data were used to determine reliability. The instrument was determined to have exemplary reliability of .9287 (Robinson, Shaver, and Wrightsman, 1991).

\section{Summary}

Over two- thirds (72.2\%) of the respondents reported having no knowledge of the FAMANCHA procedure, (FAMANCHA is a procedure used to determine the parasite load of an animal by examining the lower eyelid). More than half (55.7\%) of the respondents reported having no knowledge of fecal analysis and over one forth (31.6\%) of the respondents reported on having no knowledge of parasite control. The most respondents felt they possessed the most knowledge in tagging followed by castration and breeds. Poisonous plants were read about the most by respondents followed by goat breeds and nutritional requirements. Show related activities such as clipping of market 
and registered goats and showing of market and registered goats has been seen by over one third of the respondents. The most respondents reported performing themselves tagging and tattooing.

Gestation was learned the most (14.1\%) by respondents in their high school agriculture education program. Respondents reported gaining the most knowledge at their home or farm on tagging, followed by kidding assistance and castration.

Respondents acquired the most knowledge through work experience and on tagging, and reported acquiring the most knowledge while on the job on tagging and tattooing. Castration, vaccination programs, and parasite control were topics that respondents gained the most knowledge from formal education. The internet was the major source of knowledge on poisonous plants (19.2\%) followed by diseases (17.2\%) and nutritional requirements $(17.2 \%)$.

The respondents had the lowest confidence in teaching about embryo transfer $(85.7 \%)$ followed by artificial insemination $(73.4 \%)$, the FAMANCH procedure $(71.7 \%)$, ultrasound (72.3\%), and the nutrition of goat meat (71.4\%). Respondents had the highest confidence in teaching about tagging followed by tattooing and disbudding or dehorning. The skills mentioned in the survey were not taught by over half to three quarters of the respondents. The topics that were taught the most by the respondents were ultrasound followed by embryo transfer and fecal analysis.

Just short of all the respondents (98.9\%) agree they are in favor of the meat goat industry in West Virginia. Almost all of the respondents $(92.3 \%)$ reported they see the potential of meat goats as $4-\mathrm{H}$ and SAE projects. Most of the respondents $(97.8 \%)$ also agree on the benefits that goats have on land improvements and management and over 
half $(76.6 \%)$ are in favor of using goats as a supplemental income. Over three- fourths of the respondents $(85.8 \%)$ reported that they would attend educational programs on raising meat goats. Markets and marketing were reported by the most respondent to be programs that they would be interested in attending. Following closely was respondents that reported they would like to learn more about everything.

Just under three fourths (73.4\%) of the respondents reported that they were aware of an interest in meat goats in their community. Over half (67.1\%) of the respondents reported that the meat goat industry has increased over the past five years in their area. Over three fourth (77.9\%) of the respondents reported not having formal training in meat goat production or the meat goat industry.

\section{Conclusions}

Based on the data the following conclusions have been reached. Agriculture educators in West Virginia have little knowledge on meat goat production and the meat goat industry. A majority (67.1\%) of Extension agents and high school agriculture teachers have noticed an increase in the meat goat industry in their areas and are aware of an interest within their communities, however very few (22.2\%) of the agriculture educator have received formal training in meat goat production or the meat goat industry. Over three fourths $(79.8 \%)$ of the responds have reported they would be willing to attend formal educational programs.

\section{Recommendations}

The following recommendations are based on the knowledge and attitudes that WVU Extension agents and high school agriculture teachers in West Virginia have on meat goats and the meat goat industry. 
1. It is recommended that formal trainings in meat goats and meat goat production be made available to agriculture educators.

2. It is recommended that additional research be conducted to determine the nature of the meat goat industry present in West Virginia.

3. It is recommended that further study be conducted in the future to follow the change in the knowledge and attitudes of WVU Extension agents and high school agriculture teachers on meat goats and the meat goat industry. 


\section{REFERENCES}

About CSREES-Background. (n.d.). Retrieved February 20, 2006, from http://www.crees.usda.gov/about/background.html

About CSREES- Extension Background. (n.d.). Retrieved February 20, 2006, from http://www.crees.usda.gov/qlinks/extension.html

About the National FFA Organization. (n.d.) Retrieved February 21, 2006 from http://www.ffa.org/about_ffa/index.html

About the National FFA Organization- History. (n.d.) Retrieved February 21, 2006, from http://ffa.org/about_ffa/html/ffa_history.htm

Ary, D., Jacobs, L. C., Razavieh, A. \& Sorensen, C. (2005). Introduction to research in education. ( $7^{\text {th }}$ ed.). Belmont, CA: Thomas Wadsworth.

Coffey, L., (2002). Sustainable Goat Production: Meat Goats [Electronic Version]. ATTRA. Retrieved January 27, 2006, from http://www.attra.ncat.org/attrapub/meatgoat.html

Findlay, H.J. (1992). Where do Secondary Vocational Agriculture Teachers Acquire Professional Agricultural Education Competencies [Electronic Version]?. Journal of Agricultural Education. Retrieved February 10, 2006, from http://pubs.aged.tamu.edu/jae/pdf/Vol33/33-02-28.pdf

Gipson, T. A. (2000). Demand for Goat Meat: Implications for the Future of the Industry. Retrieved February 8, 2006, from http://www.luresext.edu/goats/library/field/goat_meat_demand99.htm

Glimp, H. A. (1995). Meat Goat Production and Marketing [Electronic Version]. Journal of Animal Science, 73, 291-295. Retrieved February 10, 2006, from http://jas.fass.org/cgi/reprint/73/1/291.pdf

4- H Curriculum Classification. (1996). REEIS Report. Retrieved February 20, 2006, from http://www.reeis.usda.gov/. (2003). REEIS Report. Retrieved February 20, 2006, from http://www.reeis.usda.gov/

4-H History. (n.d.). Retrieved February 20, 2006, from http://www.national4hheadquarters.gov/about/4h_history.htm

Hoover, T., \& Arrington, L. (n.d.). SAE Research Findings. Retrieved February 20, 2006, from http://www.cals.ncsu.edu:8050/agexed/leap/aee500/hoover.htm 
Luginbuhl, J. M. (1998). Breeds of Goats for Meat Production and Production Traits. Retrieved September 29, 2004, from http://www.cals.ncsu.edu/an_sci/extension/animal/meatgoat/MGBreed.htm

Luginbuhl, J. M. (2000). Meat Goat Production in North Carolina. Retrieved September 29, 2004, from http://www.cals.ncsu.edu/an_sci/extension/animal/meatgoat/mgproduction.html

Luginbuhl, J. M., Greene, J.T., Mueller, J.P., \& Poore, M.H. (1998). Meat Goats in Land and Forage Management. Retrieved September 26, 2004, from http://www.cals.ncsu.edu/an_sci/extension/animal/meatgoat/MGLand.htm

Mauldin, J. (n.d). Meat Goat Industry Growth Opportunity. Retrieved September 26, 2004, from http://www.jackmauldin.com/industry_growth_opportunity.htm

National Agricultural Statistics Service. (2006). Retrieved March 3, 2006, from http://usda.mannlib.cornell.edu/reports/nassr/livestock/pgg-bb/shep0106.txt

Patterson, S. (n.d.). Smith- Hughes Act of 1917 (PL347). Retrieved February 21, 2006, from http://www.arches.uga.edu/ jschell/history/legis/smithughes.htm

Pinkerton, F., Harwell, L., Drinkwater, W., \& Escobar, N. (1994) Marketing Meat Goats: Channels, Supply and Demand. M-03. Retrieved February 8, 2006, from http://www.luresext.edu/goats/library/fact_sheets/m03.htm

Schoenian, S. (n.d.). Meat Goat Production. Retrieved September 29, 2004, from http://www.sheepandgoat.com/articles/meatgoats.htm 
APPENDICES 
APPENDIX A

Survey Instrument 
Attitudes and Knowledge of Meat Goats and the Meat Goat Industry in West

Virginia by Agricultural Teachers and

WVU Extension Agents

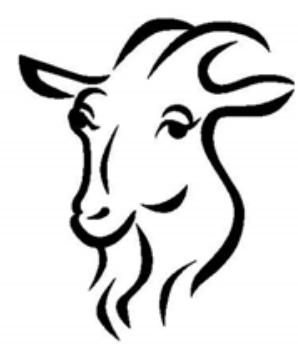

Angie Kirk

Graduate Student

Agricultural and Environmental Education

Davis College of Agriculture, Forestry, and Consumer Sciences

West Virginia University

Morgantown, $W V 26506$ 


\section{Attitudes and Knowledge of Meat Goats and the Meat Goat Industry in West Virginia by Agricultural Teachers and WVU Extension Agents Survey}

Instructions: Using the following scales please circle your performance level on the following topics related to the meat goat industry, source of knowledge, confidence in teaching the topic, number of times you taught the topic in the past year and method(s) you used to teach the topic. (Note: For source of knowledge and teaching method(s), please circle all that apply.)

\begin{tabular}{|c|c|c|c|c|c|c|c|c|c|c|c|c|c|c|c|c|c|c|c|c|c|c|}
\hline \multirow[t]{2}{*}{ Skill } & \multicolumn{5}{|c|}{$\begin{array}{l}\text { (A) } \\
\text { Knowledge Level-Rate your } \\
\text { performance ability with the given } \\
\text { topic. }\end{array}$} & \multicolumn{6}{|c|}{$\begin{array}{l}\text { (B) } \\
\text { Source of Knowledge - Where did you } \\
\text { acquire your knowledge of the topic? } \\
\text { (please circle all that apply) }\end{array}$} & \multicolumn{5}{|c|}{$\begin{array}{l}(\mathbf{C}) \\
\text { Confidence - How confident are } \\
\text { you that you can perform or teach } \\
\text { the topic? }\end{array}$} & \multirow[t]{2}{*}{$\begin{array}{l}\text { (D) } \\
\text { Number of } \\
\text { Times Topic } \\
\text { was Taught } \\
\text { in Past year }\end{array}$} & \multicolumn{5}{|c|}{$\begin{array}{c}\text { (E) } \\
\text { Teaching Method(s) Used } \\
\text { (please circle all that apply) }\end{array}$} \\
\hline & 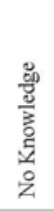 & 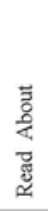 & 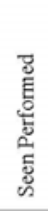 & 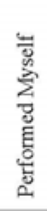 & 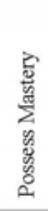 & 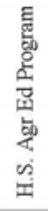 & 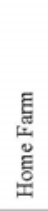 & 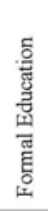 & 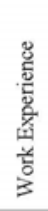 & $\begin{array}{l}\stackrel{2}{0} \\
\stackrel{5}{5} \\
0\end{array}$ & 导 & $\frac{3}{3}$ & $\underline{z}$ & 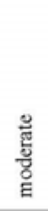 & 毛 & 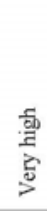 & & 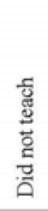 & 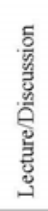 & 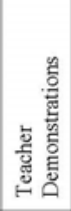 & 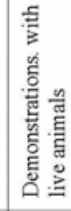 & 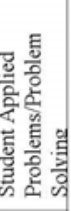 \\
\hline 1. Nutritional Requirements & 1 & 2 & 3 & 4 & 5 & 1 & 2 & 3 & 4 & 5 & 6 & 1 & 2 & 3 & 4 & 5 & & 1 & 2 & 3 & 4 & 5 \\
\hline 2. Parasite Control & 1 & 2 & 3 & 4 & 5 & 1 & 2 & 3 & 4 & 5 & 6 & 1 & 2 & 3 & 4 & 5 & & 1 & 2 & 3 & 4 & 5 \\
\hline 3. Performing Fecal Analysis & 1 & 2 & 3 & 4 & 5 & 1 & 2 & 3 & 4 & 5 & 6 & 1 & 2 & 3 & 4 & 5 & & 1 & 2 & 3 & 4 & 5 \\
\hline 4. FAMANCHA Procedure & 1 & 2 & 3 & 4 & 5 & 1 & 2 & 3 & 4 & 5 & 6 & 1 & 2 & 3 & 4 & 5 & & 1 & 2 & 3 & 4 & 5 \\
\hline 5. Common Diseases & 1 & 2 & 3 & 4 & 5 & 1 & 2 & 3 & 4 & 5 & 6 & 1 & 2 & 3 & 4 & 5 & & 1 & 2 & 3 & 4 & 5 \\
\hline 6. Poisonous Plants & 1 & 2 & 3 & 4 & 5 & 1 & 2 & 3 & 4 & 5 & 6 & 1 & 2 & 3 & 4 & 5 & & 1 & 2 & 3 & 4 & 5 \\
\hline 7. Vaccination Programs & 1 & 2 & 3 & 4 & 5 & 1 & 2 & 3 & 4 & 5 & 6 & 1 & 2 & 3 & 4 & 5 & & 1 & 2 & 3 & 4 & 5 \\
\hline 8. Scrapies ID & 1 & 2 & 3 & 4 & 5 & 1 & 2 & 3 & 4 & 5 & 6 & 1 & 2 & 3 & 4 & 5 & & 1 & 2 & 3 & 4 & 5 \\
\hline 9. Temperature & 1 & 2 & 3 & 4 & 5 & 1 & 2 & 3 & 4 & 5 & 6 & 1 & 2 & 3 & 4 & 5 & & 1 & 2 & 3 & 4 & 5 \\
\hline 10. Heart Rate & 1 & 2 & 3 & 4 & 5 & 1 & 2 & 3 & 4 & 5 & 6 & 1 & 2 & 3 & 4 & 5 & & 1 & 2 & 3 & 4 & 5 \\
\hline 11. Respiration & 1 & 2 & 3 & 4 & 5 & 1 & 2 & 3 & 4 & 5 & 6 & 1 & 2 & 3 & 4 & 5 & & 1 & 2 & 3 & 4 & 5 \\
\hline 12. Gestation & 1 & 2 & 3 & 4 & 5 & 1 & 2 & 3 & 4 & 5 & 6 & 1 & 2 & 3 & 4 & 5 & & 1 & 2 & 3 & 4 & 5 \\
\hline
\end{tabular}




\begin{tabular}{|c|c|c|c|c|c|c|c|c|c|c|c|c|c|c|c|c|c|c|c|c|c|c|}
\hline \multirow[t]{2}{*}{ Skill } & \multicolumn{5}{|c|}{$\begin{array}{l}\text { (A) } \\
\text { Knowledge Level - Rate your } \\
\text { performance ability with the given } \\
\text { topic. }\end{array}$} & \multicolumn{6}{|c|}{$\begin{array}{l}\text { (B) } \\
\text { Source of Knowledge - Where did you } \\
\text { acquire your knowledge of the topic? } \\
\text { (please circle all that apply) }\end{array}$} & \multicolumn{5}{|c|}{$\begin{array}{c}\text { (C) } \\
\text { Confidence - How confident are } \\
\text { you that you can perform or teach } \\
\text { the topic? }\end{array}$} & \multirow[t]{2}{*}{$\begin{array}{l}\text { (D) } \\
\text { Number of } \\
\text { Times Topic } \\
\text { was Taught } \\
\text { in Past year }\end{array}$} & \multicolumn{5}{|c|}{$\begin{array}{c}\text { (E) } \\
\text { Teaching Method(s) Used } \\
\text { (please circle all that apply) }\end{array}$} \\
\hline & 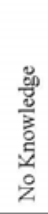 & 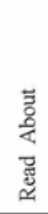 & 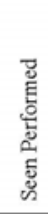 & 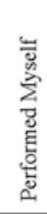 & 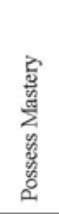 & 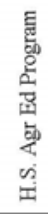 & 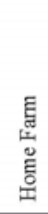 & 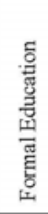 & 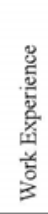 & 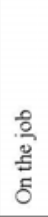 & 莺 & 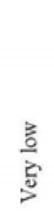 & $\underline{z}$ & 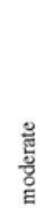 & 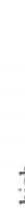 & 哥 & & 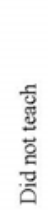 & 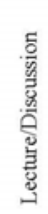 & م. & 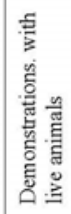 & 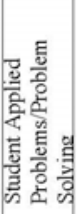 \\
\hline 13. Tattooing & 1 & 2 & 3 & 4 & 5 & 1 & 2 & 3 & 4 & 5 & 6 & 1 & 2 & 3 & 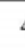 & 5 & & 1 & 2 & 3 & 4 & 5 \\
\hline 14. Hoof trimming & 1 & 2 & 3 & 4 & 5 & 1 & 2 & 3 & 4 & 5 & 6 & 1 & 2 & 3 & 2 & 5 & & 1 & 2 & 3 & 4 & 5 \\
\hline 15. Assisting in kidding & 1 & 2 & 3 & 4 & 5 & 1 & 2 & 3 & 4 & 5 & 6 & 1 & 2 & 3 & 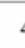 & 5 & & 1 & 2 & 3 & 4 & 5 \\
\hline 16. Artificial Insemination & 1 & 2 & 3 & 4 & 5 & 1 & 2 & 3 & 4 & 5 & 6 & 1 & 2 & 3 & 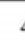 & 5 & & 1 & 2 & 3 & 4 & 5 \\
\hline 17. Embryo transfer & 1 & 2 & 3 & 4 & 5 & 1 & 2 & 3 & 4 & 5 & 6 & 1 & 2 & 3 & 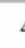 & 5 & & 1 & 2 & 3 & 4 & 5 \\
\hline 18. Ultrasound & 1 & 2 & 3 & 4 & 5 & 1 & 2 & 3 & 4 & 5 & 6 & 1 & 2 & 3 & 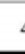 & 5 & & 1 & 2 & 3 & 4 & 5 \\
\hline 19. Disbudding/dehorning & 1 & 2 & 3 & 4 & 5 & 1 & 2 & 3 & 4 & 5 & 6 & 1 & 2 & 3 & 2 & 5 & & 1 & 2 & 3 & 4 & 5 \\
\hline 20. Castrating & 1 & 2 & 3 & 4 & 5 & 1 & 2 & 3 & 4 & 5 & 6 & 1 & 2 & 3 & 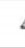 & 5 & & 1 & 2 & 3 & 4 & 5 \\
\hline 21. Tagging & 1 & 2 & 3 & 4 & 5 & 1 & 2 & 3 & 4 & 5 & 6 & 1 & 2 & 3 & 2 & 5 & & 1 & 2 & 3 & 4 & 5 \\
\hline 22. Predator control & 1 & 2 & 3 & 4 & 5 & 1 & 2 & 3 & 4 & 5 & 6 & 1 & 2 & 3 & 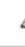 & 5 & & 1 & 2 & 3 & 4 & 5 \\
\hline 23. Breeds & 1 & 2 & 3 & 4 & 5 & 1 & 2 & 3 & 4 & 5 & 6 & 1 & 2 & 3 & 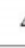 & 5 & & 1 & 2 & 3 & 4 & 5 \\
\hline 24. Showing Market Goats & 1 & 2 & 3 & 4 & 5 & 1 & 2 & 3 & 4 & 5 & 6 & 1 & 2 & 3 & 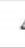 & 5 & & 1 & 2 & 3 & 4 & 5 \\
\hline 25. Showing Registered Goats & 1 & 2 & 3 & 4 & 5 & 1 & 2 & 3 & 4 & 5 & 6 & 1 & 2 & 3 & 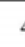 & 5 & & 1 & 2 & 3 & 4 & 5 \\
\hline 26. Clipping for market shows & 1 & 2 & 3 & 4 & 5 & 1 & 2 & 3 & 4 & 5 & 6 & 1 & 2 & 3 & 2 & 5 & & 1 & 2 & 3 & 4 & 5 \\
\hline 27. Clipping for reg. shows & 1 & 2 & 3 & 4 & 5 & 1 & 2 & 3 & 4 & 5 & 6 & 1 & 2 & 3 & 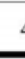 & 5 & & 1 & 2 & 3 & 4 & 5 \\
\hline 28. Ethnic Calendars & 1 & 2 & 3 & 4 & 5 & 1 & 2 & 3 & 4 & 5 & 6 & 1 & 2 & 3 & 2 & 5 & & 1 & 2 & 3 & 4 & 5 \\
\hline
\end{tabular}




\begin{tabular}{|c|c|c|c|c|c|c|c|c|c|c|c|c|c|c|c|c|c|c|c|c|c|c|}
\hline \multirow[t]{2}{*}{ Skill } & \multicolumn{5}{|c|}{$\begin{array}{c}\text { (A) } \\
\text { Knowledge Level-Rate your } \\
\text { performance ability with the given } \\
\text { topic. }\end{array}$} & \multicolumn{6}{|c|}{$\begin{array}{l}\text { (B) } \\
\text { Source of Knowledge-Where did you } \\
\text { acquire your knowledge of the topic? } \\
\text { (please circle all that apply) }\end{array}$} & \multicolumn{5}{|c|}{$\begin{array}{c}\text { (C) } \\
\text { Confidence - How confident are } \\
\text { you that you can perform or teach } \\
\text { the topic? }\end{array}$} & \multirow[t]{2}{*}{$\begin{array}{l}\text { (D) } \\
\text { Number of } \\
\text { Times Topic } \\
\text { was Taught } \\
\text { in Past year }\end{array}$} & \multicolumn{5}{|c|}{$\begin{array}{c}\text { (E) } \\
\quad \text { Teaching Method(s) Used } \\
\text { (please circle all that apply) }\end{array}$} \\
\hline & 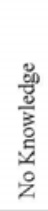 & 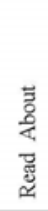 & 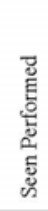 & 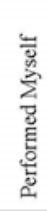 & 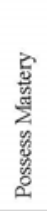 & 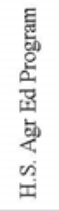 & 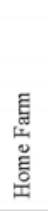 & 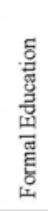 & 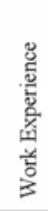 & 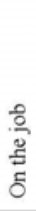 & 岕 & $\frac{\text { o }}{2}$ & $\underline{\partial}$ & 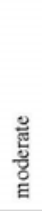 & 맬 & 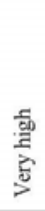 & & 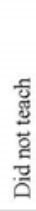 & 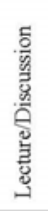 & 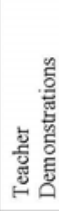 & 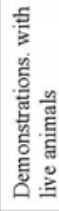 & 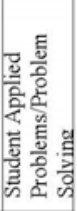 \\
\hline 29. Available markets & 1 & 2 & 3 & 4 & 5 & 1 & 2 & 3 & 4 & 5 & 6 & 1 & 2 & 3 & 4 & 5 & & 1 & 2 & 3 & 4 & 5 \\
\hline 30. Genetics & 1 & 2 & 3 & 4 & 5 & 1 & 2 & 3 & 4 & 5 & 6 & 1 & 2 & 3 & 4 & 5 & & 1 & 2 & 3 & 4 & 5 \\
\hline 31. Selection & 1 & 2 & 3 & 4 & 5 & 1 & 2 & 3 & 4 & 5 & 6 & 1 & 2 & 3 & 4 & 5 & & 1 & 2 & 3 & 4 & 5 \\
\hline 32. Out of season breeding & 1 & 2 & 3 & 4 & 5 & 1 & 2 & 3 & 4 & 5 & 6 & 1 & 2 & 3 & 4 & 5 & & 1 & 2 & 3 & 4 & 5 \\
\hline 33. Carcass yields & 1 & 2 & 3 & 4 & 5 & 1 & 2 & 3 & 4 & 5 & 6 & 1 & 2 & 3 & 4 & 5 & & 1 & 2 & 3 & 4 & 5 \\
\hline 34. Weight gain & 1 & 2 & 3 & 4 & 5 & 1 & 2 & 3 & 4 & 5 & 6 & 1 & 2 & 3 & 4 & 5 & & 1 & 2 & 3 & 4 & 5 \\
\hline $\begin{array}{l}\text { 35. Nutritional analysis of goat } \\
\text { meat }\end{array}$ & 1 & 2 & 3 & 4 & 5 & 1 & 2 & 3 & 4 & 5 & 6 & 1 & 2 & 3 & 4 & 5 & & 1 & 2 & 3 & 4 & 5 \\
\hline
\end{tabular}


Instructions: Please circle your rating of the following statements using the following sale: SD - Strongly Disagree, D - Disagree, A - Agree, and SA - Strongly Agree.

\begin{tabular}{|l|c|c|c|c|}
\hline & & & & \\
\hline & SD & D & & \\
\hline 36. I am in favor of the meat goat industry in WV & SD & D & A & SA \\
\hline 37. I promote the meat goat industry in WV & SD & D & A & SA \\
\hline 38. I see a future for the meat goat industry in WV & SD & D & A & SA \\
\hline $\begin{array}{l}\text { 39. I am in favor of market goat shows at the county } \\
\text { level for youth }\end{array}$ & SD & D & A & SA \\
\hline $\begin{array}{l}\text { 40. I promote market goat shows at the county level for } \\
\text { youth }\end{array}$ & SD & D & A & SA \\
\hline $\begin{array}{l}\text { 41. I see the potential of market goats as 4-H projects } \\
\text { and SAEs }\end{array}$ & SD & D & A & SA \\
\hline $\begin{array}{l}\text { 42. I see the benefits goats have on land improvements } \\
\text { and management }\end{array}$ & SD & D & A & SA \\
\hline $\begin{array}{l}\text { 43. I am in favor of using meat goats as a source of } \\
\text { supplemental income }\end{array}$ & SD & D & A & SA \\
\hline $\begin{array}{l}\text { 44. I promote using meat goats as a source of } \\
\text { supplemental income }\end{array}$ & SD & D & A & SA \\
\hline $\begin{array}{l}\text { 45. I believe the future of the meat goat industry in WV } \\
\text { is strong }\end{array}$ & SD & D & A & SA \\
\hline $\begin{array}{l}\text { 46. I would attend an educational program on raising } \\
\text { meat goats }\end{array}$ & SD & D & A & SA \\
\hline
\end{tabular}

47. I would be interested in attending the following educational topics on the meat goat industry.

48. What is your current position:

$$
\text { a. Extension Agent }
$$

a. Extension Agent

49. Are you aware of an interest in meat goats in your community?

$$
\begin{array}{ll}
\text { a. Yes } \\
\text { b. No }
\end{array}
$$

50. Within the industry, how would you rate the demand for goat meat? a. High demand

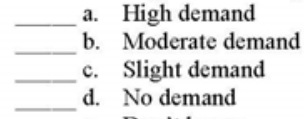

c. Slight deman

e. Don't know

51. Please indicate which type(s) of livestock you personally raise? ( Check all that apply) a. Meat Goats

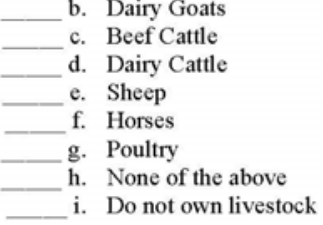


52. What markets are available for meat goat producers in your area? (Check all that apply) a. Local livestock markets

Goat pools

Registered goat consignment sales

Market/ club goat consignment sales

Directly off the farm

No markets in our are

g. Don't know

53. To your knowledge how has the meat goat industry in your area changed in the past 5 years? a. Increased

Decreased

C. Stayed the same

54. Have you had formal training on meat goat production or the meat goat industry? Yes

55. If so, please list the types of training and the number of hours in each.

$-\overline{-}$

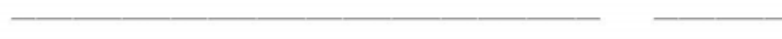

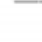

$-$

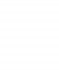


APPENDIX B

Initial Cover Letter 
January 6, 2006

Dear West Virginia Agricultural Educators:

Meat goat production has been receiving more emphasis in many states across the nation. As a result of my personal interests and experiences with the meat goat industry, I am interested in gathering additional information and insight into the knowledge, attitudes and perceptions of agricultural educators' towards meat goats and the meat goat industry.

The purpose of this research study is to determine agricultural educators' knowledge, attitudes, and perceptions of the meat goat industry in West Virginia. The results of this study will be used to prepare a thesis to partially fulfill the requirements for a Master of Science in Agricultural Education. By determining the knowledge, and attitudes toward the meat goat industry, programs can be developed to increase knowledge and training to meet the needs of agricultural educators.

Participation in this research study is completely voluntary and all information you provide will be held as confidential as possible. Your response to the survey will be critical to the success of the study, and will only take a few minutes of your time to complete. You may skip any question you are not comfortable answering. Survey results will be reported in a summary format and individual responses will not be identifiable.

Once you complete the questionnaire, place the completed questionnaire and survey in the enclosed postage-paid self-addressed envelope and drop it in the mail.

\section{Please return your completed questionnaire by January 25, 2006.}

You will notice a code number at the top left of the return envelope. This code will be used to identify non-respondents for follow-up and will be destroyed before the data are analyzed. Thank you in advance for your assistance with this research effort. We sincerely appreciate your time and effort

Sincerely,

Angela L. Kirk Deborah A. Boone, Ph.D. Graduate Student Assistant Professor 
APPENDIX C

Follow-up Cover Letter 
February 7, 2006

Dear West Virginia Agricultural Educators:

On January 11 we sent you a questionnaire about the meat goat industry. As of today, we have not received your reply; we are enclosing a second copy of the survey and hope you will complete and return. Please complete and return even if you know nothing about goats. If you have already returned the first one there is no need to complete this one, we sincerely appreciate your participation.

Meat goat production has been receiving more emphasis in many states across the nation. As a result of my personal interests and experiences with the meat goat industry, I am interested in gathering additional information and insight into the knowledge, attitudes and perceptions of agricultural educators' towards meat goats and the meat goat industry.

The purpose of this research study is to determine agricultural educators' knowledge, attitudes, and perceptions of the meat goat industry in West Virginia. The results of this study will be used to prepare a thesis to partially fulfill the requirements for a Master of Science in Agricultural Education. By determining the knowledge, and attitudes toward the meat goat industry, programs can be developed to increase knowledge and training to meet the needs of agricultural educators.

Participation in this research study is completely voluntary and all information you provide will be held as confidential as possible. Your response to the survey will be critical to the success of the study, and will only take a few minutes of your time to complete. You may skip any question you are not comfortable answering. Survey results will be reported in a summary format and individual responses will not be identifiable.

Place the completed questionnaire in the enclosed postage-paid self-addressed envelope and drop it in the mail. Please return your completed questionnaire by February 22, 2006. You will notice a code number at the top left of the return envelope. This code will be used to identify non-respondents for follow-up and will be destroyed before the data are analyzed. Thank you in advance for your assistance with this research effort. We sincerely appreciate your time and effort

Sincerely,

Angela L. Kirk

Graduate Student
Deborah A. Boone, Ph.D.

Assistant Professor 


\section{APPENDIX D}

Open-ended Responses to Question 47 
Open Ended Responses to Question 47: I would be interested in attending the following educational topics on the meat goat industry.

\section{Response (number of Respondents)}

4- H shows
AI
Basics
Benefits
Breeding
Clipping (2)
Co-op
Disease (3)
Equip.
Ethnic cal.
Everything (6)
FAMACHA training
Feeding
Fencing (2)
General
Getting started
Health
Herd management
How to start
Husbandry
Introduction
Management (7)
Market workshop
Marketing (7)
Markets (3)
Nutrition (4)
Parasites (4)
Parasite control
Predator
Processing
Production (6)
Selection (3)
Showing (4)
Vaccinations 


\section{APPENDIX E}

Open-ended Responses to Question 55 
Open Ended Responses to Question 55: If you have received formal training, please list the types of events and the number of contact hours on each.

\section{Response (number of contact hours)-(number of responses)}

Small ruminants $(2 \mathrm{hrs}$ )

$\mathrm{GCC} \mathrm{wv} / \mathrm{md} /$ pa goat con. (6 hrs)

AI ( $8 \mathrm{hrs})$

Dinner

Ed. Evening mtg.(6 hrs.)

Extension

FAMANCHA ( $3 \mathrm{hrs})-$ ( 3 respondents)

FAMANCHA ( $4 \mathrm{hrs})-(2$ respondents $)$

FAMANCHA ( $8 \mathrm{hrs})$

Fecal (3 hrs)

Fecal egg (4 hrs)

Fecal egg (5 hrs)

Forage

Goat health WVUES @ J.Mill (2 hrs)

Judging school

Management (4 hrs)

Marketing

Meeting ( 2 hrs)

Meetings (14 hrs)

Nutrition (2 hrs)

Parasites

Parasites (5 hrs)

Parasites (2 hrs)

Production (2 hrs)

Sm. Ruminants

Sm. Ruminants (8 hrs)

$\mathrm{Va} / \mathrm{NC}$ conf. (24 hrs)

Workshops 
VITA

Angela L. Kirk

\section{Education:}

May 2006

May 2003

\section{Work Experience:}

April 2004 - Present
Master of Science in Agricultural and Extension Education West Virginia University

Bachelor of Science in Animal and Veterinary Sciences West Virginia University

\author{
Farm Supervisor \\ Potomac State College \\ Keyser, WV
}

